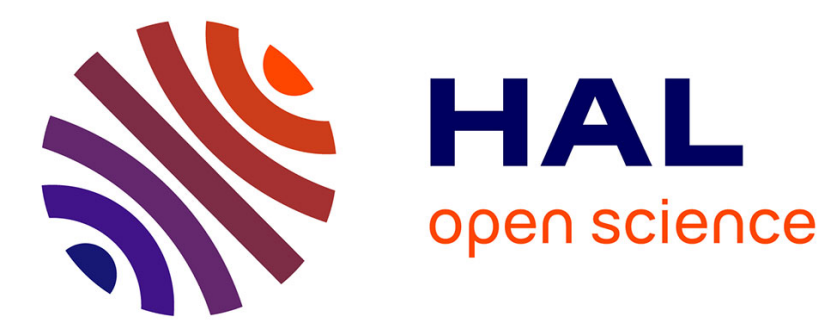

\title{
Auxinic Herbicide Conjugates with an $\alpha$-Amino Acid Function: Structural Requirements for Biological Activity on Motor Cells
}

\author{
Gabriel Roblin, Jean-Louis Bonnemain, Jean-François Chollet
}

\section{To cite this version:}

Gabriel Roblin, Jean-Louis Bonnemain, Jean-François Chollet. Auxinic Herbicide Conjugates with an $\alpha$-Amino Acid Function: Structural Requirements for Biological Activity on Motor Cells. Plant Physiology and Biochemistry, 2020, 155, pp.444-454. 10.1016/j.plaphy.2020.07.014 . hal-02895065

\section{HAL Id: hal-02895065 \\ https://hal.science/hal-02895065}

Submitted on 9 Jul 2020

HAL is a multi-disciplinary open access archive for the deposit and dissemination of scientific research documents, whether they are published or not. The documents may come from teaching and research institutions in France or abroad, or from public or private research centers.
L'archive ouverte pluridisciplinaire HAL, est destinée au dépôt et à la diffusion de documents scientifiques de niveau recherche, publiés ou non, émanant des établissements d'enseignement et de recherche français ou étrangers, des laboratoires publics ou privés. 
Auxinic Herbicide Conjugates with an $\alpha$-Amino Acid Function: Structural Requirements for Biological Activity on Motor Cells

Running head:

Bioactivity of auxinic herbicide conjugates

* Corresponding author: J.-F. Chollet ; IC2MP (Institut de Chimie des Milieux et des Matériaux de Poitiers), UMR CNRS 7285, Université de Poitiers, 4 rue Michel Brunet, TSA 51106, F-86073 Poitiers Cedex 9, France

Number of black and white figures: 8 ; color figures: 0 ; tables: 4; type and number of supplementary materials: 0 


\section{Auxinic Herbicide Conjugates with an $\alpha$-Amino Acid Function: Structural Requirements for Biological Activity on Motor Cells}

\section{Running head:}

Bioactivity of auxinic herbicide conjugates

Gabriel Roblin $^{1}$, Jean-Louis Bonnemain ${ }^{1}$, Jean-François Chollet ${ }^{2 *}$

${ }^{1}$ Laboratoire EBI (Écologie et Biologie des Interactions), UMR CNRS EBI 6267, Équipe SEVE (Sucres, Échanges Végétaux, Environnement) du Transport, Université de Poitiers, 3 rue Jacques Fort, TSA 51106, F-86073 Poitiers Cedex 9, France

${ }^{2}$ IC2MP (Institut de Chimie des Milieux et des Matériaux de Poitiers), UMR CNRS 7285, Université de Poitiers, 4 rue Michel Brunet, TSA 51106, F-86073 Poitiers Cedex 9, France

* Corresponding author: J.-F. Chollet; jean.francois.chollet@univ-poitiers.fr 


\begin{abstract}
Two Fabaceae exhibiting rapid osmocontractile pulvinar movements were used in this study because this activity is modified by natural auxin and dramatically by $2,4 \mathrm{D}$. A short chain with a carboxylic group being required for auxinic properties, a critical point to analyze is whether the recently synthesized proherbicide $\varepsilon$-(2,4-dichlorophenoxyacetyl)-L-Lys (2-4DL-Lys) maintains some biological activity despite the increase in length of the chain and the substitution of the carboxyl group by an $\alpha$-amino acid function. No trace of $2,4 \mathrm{D}$ could be detected in the pulvinar tissues treated for one hour with 2,4D-L-Lys. Complementary approaches (electrophysiology, $\mathrm{pH}$ measurements, use of plasma membrane vesicles) suggest that it was less efficient than $2,4 \mathrm{D}$ to activate the plasma membrane $\mathrm{H}^{+}$-ATPase $\left(\mathrm{PM}-\mathrm{H}^{+}\right.$ATPase). However, it modified the various ion-driven reactions of Mimosa pudica and Cassia fasciculata pulvini in a similar way as $2,4 \mathrm{D}$. Additionally, it was much more effective than fusicoccin to inhibit seismonastic movements of $M$. pudica leaves and, at low concentrations, to promote leaflet opening in dark, indicating that its mode of action is more complex than the only activation of the PM- $\mathrm{H}^{+}$-ATPase. Various substitutions on 2,4D-L-Lys affected its activity in correlation with the molecular descriptor "halogen ratio" of these derivatives. Conjugation with D-Lys also led to a decrease of pulvinar reaction, suggesting that 2,4D-Lys maintains the main signaling properties of 2,4D involved in pulvinar movements providing that the terminal zwitterion is in a suitable orientation. Our data guide future investigations on the effect of 2,4D and 2,4D-L-Lys on the vacuolar pump activity of motor cells.
\end{abstract}

Keywords: amino acid conjugate, fusicoccin, ion driven reactions, motor cells, $\mathrm{PM}-\mathrm{H}^{+}-$ ATPase, synthetic auxin, vacuolar membrane 


\section{Introduction}

In previous works, the synthesis of several phenoxyalkanecarboxylic acids and L-lysine (Lys) conjugates have been carried out (Chollet et al., 1997, Dufaud et al., 1994) to evaluate the ability of amino acid carriers to translocate chlorinated compounds larger than their natural substrates. While in the in vivo conjugation, indole-3-acetic acid (IAA) is covalently bounded through its carboxylic group to the amine function of the amino acid, the conjugates which have been synthetized preserved their free $\alpha$-amino acid function (Chollet et al., 1997, Dufaud et al., 1994). We have shown that 2,4-dichlorophenoxyacetyl-L-lysine (2,4D-L-Lys, Table 1), one of the largest conjugates, is translocated by an active carrier system. It is highly phloem mobile but exhibits, from mature Vicia faba leaves, a distribution pattern clearly different from that of 2,4-dichlorophenoxyacetic acid (2,4D) and L-Lysine in short time experiments (Delétage-Grandon et al., 2001). Over time, 2,4D-L-Lys progressively splits into 2,4D and Lys. About 1/8 and 1/4 of the amount of 2,4D-L-Lys absorbed by leaf tissues discs for $1 \mathrm{~h}$ are extracted as 2,4D after $5 \mathrm{~h}$ and $23 \mathrm{~h}$ of ageing respectively (Delétage-Grandon et al., 2001). In comparison with 2,4D treatments, epinasty and herbicidal effect occur with a delay of few hours and 1-3 days, respectively. Therefore, tissue and organ death is logically due to the herbicide $2,4 \mathrm{D}$.

It has been known for a long time that increase in length of 2,4D side chain abolish completely or almost completely its auxinic-herbicidal activity (Leopold, 1955, Synerholm and Zimmerman, 1947). Therefore, it may be questioned whether some biological properties of $2,4 \mathrm{D}$ are maintained in the conjugate despite the dramatic changes in chain structure. In order to answer this question, we investigated the effect of 2,4D-L-Lys on the responses of pulvinar motor cells of Mimosa pudica and Cassia fasciculata, two plant models already used previously to study the effect of $2,4 \mathrm{D}$ as indicated below. While the anisotropic growth of meristematic tissues in response to lateral light leads to an irreversible directional curvature 
(Pietruszka and Lewicka, 2007), the motor cells exhibit changes in shape and volume only when they are mature. Both species exhibit rhythmic leaf movements in synchrony with diurnal alternations of light and dark periods of the nycthemeral cycle (Roblin, 1977). These movements are governed by osmotic changes due to ion redistribution (mainly $\mathrm{K}^{+}$and $\mathrm{Cl}^{-}$) and water fluxes in flexor and extensor cells of pulvini (Coté, 1995, Moran, 2007). In addition, several types of environmental variations quickly induce modifications in the motor cell machinery that are expressed by rapid movements of the leaves as well as other organs (Scorza and Dornelas, 2011). Spectacularly, the leaf drooping of Mimosa pudica following a mechanical shock on the primary pulvinus is achieved in about $2 \mathrm{~s}$ (Roblin, 1976, Volkov et al., 2010) (Fig. 1A-C). This movement, which is triggered by action potentials, involves at first, in addition to a cellular redistribution of $\mathrm{Ca}^{2+}$ and changes in the actin cytoskeleton (Fleurat-Lessard et al., 1993, Yao et al., 2008), a sudden and intense efflux of $\mathrm{K}^{+}$and $\mathrm{Cl}^{-}$ through specific ion channels and water through aquaporins (TIPs and PIPs) from the symplasm to the apoplasm of the extensor motor cells (Fleurat-Lessard et al., 1997, Scorza and Dornelas, 2011, Temmei et al., 2005, Volkov et al., 2010). In the model of Cassia fasciculata leaf, leaflet movements can be distinctly induced in 15-30 min by transferring plants from light to darkness (scotonasty) or from darkness to light (photonasty) (Fig. 1D). Noteworthy, these movements are positively or negatively affected by compounds which modulate the activity of the plasma membrane $\mathrm{H}^{+}$-ATPase (PM- $\left.\mathrm{H}^{+}-\mathrm{ATPase}\right)$, a proton pump highly expressed in motor cells (Fleurat-Lessard et al., 1997). For instance, the fungal toxin fusicoccin (FC) and indole-3-acetic (IAA) which both increase the activity of this proton pump (Hager, 2003, Takahashi et al., 2012) inhibit the scotonastic movement and induce an opening of C. fasciculata leaflets and M. pudica pinnules in dark conditions (Bonnemain et al., 1978, Éverat-Bourbouloux et al., 1990). By contrast, abscisic acid (ABA) which inhibits PM- $\mathrm{H}^{+}$-ATPase activity (Hayashi et al., 2014) induces leaflet closure in light conditions 
(Bonnemain et al., 1978). In our concern, it has been shown that the synthetic auxin 2,4D inhibits the shock-induced pulvinar reaction (Moyen et al., 2007) and also inhibits scotonastic closure and promotes photonastic opening (Bonmort and Roblin, 1996).

Having in mind the structural requirements for auxinic activity (Leopold, 1955), the purpose of this paper was firstly to compare, using the M. pudica model, the effects of 2,4DL-Lys with those of 2,4D and FC already reported on pulvinar osmocontractile reactions triggered by a shock in relation to early events possibly induced by the conjugate at cell plasma membrane level. This study has been made possible because the conjugate has been shown to be more stable in pulvini than in other plant materials previously used. Secondly, the effects of 2,4D-L-Lys on dark- and light-induced reactions of C. fasciculata leaflets were compared with those already published using 2,4D and FC. The data led us to study the structure/biological activity relationships using 2,4D-L-Lys analogs with various substituents on the aromatic ring or the chain.

\section{Materials and methods}

\subsection{Plant growth conditions}

Seeds of Mimosa pudica L. and Cassia fasciculata Michx. were germinated in an organic compost and seedlings and older plants were grown in this compost watered daily. They were kept in climate-controlled chambers at $27.5 \pm 0.5{ }^{\circ} \mathrm{C}$ and $65 \pm 5 \%$ relative humidity. Illumination was regulated to give $16 \mathrm{~h}$ of light (photophase $06.00 \mathrm{am}-22.00 \mathrm{pm}$ ) provided by fluorescent tubes (mixing Osram fluora and Osram day-light types) with a photon flux density of $80 \mu \mathrm{mol} \mathrm{m} \mathrm{m}^{-2} \mathrm{~s}^{-1}$ at the plant apex.

\subsection{Uptake assays and metabolization experiments of 2,4D-L-Lys}

The uptake of $0.1 \mathrm{mM}\left[{ }^{3} \mathrm{H}\right]$ 2,4D-L-Lys (final specific activity of the medium $8 \mathrm{kBq} \cdot \mathrm{ml}^{-}$

${ }^{1}$ ) was monitored by sectioning primary pulvini from the leaves of the plantlet model with a 
razor blade at $1 \mathrm{~h}$ intervals. The excised organs ( 5 by set) were weighed and digested in a cocktail of $30 \%$ hydrogen peroxide, $70 \%$ perchloric acid and triton X100 (2/1/1 by vol.) for $24 \mathrm{~h}$ at $55{ }^{\circ} \mathrm{C}$. The radioactivity was then counted after addition of a scintillation medium (Ecolite, ICN) by liquid scintillation spectrometry (Packard Instruments). The experiments were repeated three times.

To study the possible metabolization of 2,4D-L-Lys, leaves of $M$. pudica were excised from the stem of 2-month-old plant and pulvini were dipped for $2 \mathrm{~h}$ in a buffered solution $(\mathrm{pH}$ 5.2) of the same composition as that used for electrophysiological assays. Then, after treatments for 1 and $2 \mathrm{~h}$ in the medium containing $100 \mu \mathrm{M}$ 2,4D-L-Lys, the pulvini were rinsed in buffer solution, harvested and ground in liquid nitrogen using mortar and pestle. The resulting powder was extracted with $10 \mathrm{ml}$ of an ethanol/water mixture $(80 / 20 ; \mathrm{v} / \mathrm{v})$. The liquid phase was separated by centrifugation and the solvent was removed under reduced pressure. The residue was then dissolved in $800 \mu \mathrm{l}$ of an ethanol/water mixture $(50 / 50 ; \mathrm{v} / \mathrm{v})$ and an aliquot $(20 \mu 1)$ was analyzed by HPLC using a Supelco Ascentis ${ }^{\circledR}$ Express RP-Amide column (length, $250 \mathrm{~mm}$; i.d., $4.6 \mathrm{~mm}$ ). The mobile phase consisted of water with $0.01 \%$ TFA (A) and acetonitrile (B) with a flow rate of $0.8 \mathrm{ml} \cdot \mathrm{min}^{-1}$. Using the following gradient allowed to separate $2,4 \mathrm{D}-\mathrm{L}-\mathrm{Lys}($ retention time $=5.5 \mathrm{~min})$ and $2,4 \mathrm{D}($ retention time $=19.7 \mathrm{~min}): \mathrm{t}=0$ $\min , 70 \% \mathrm{~A}+30 \% \mathrm{~B} ; \mathrm{t}=25 \min , 50 \% \mathrm{~A}+50 \% \mathrm{~B} ; \mathrm{t}=30 \min , 70 \% \mathrm{~A}+30 \% \mathrm{~B} ; \mathrm{t}=35 \min$, $70 \% \mathrm{~A}+30 \% \mathrm{~B}$. A UV detector was used at a wavelength of $202 \mathrm{~nm}$.

\subsection{Electrophysiological measurement and measurement of $p H$ variations}

The transmembrane potential was measured by the classical electrophysiological method using microelectrodes (tip diameter $<1 \mu \mathrm{m}$, tip resistance from 5 to $30 \mathrm{M} \Omega$ ). For details, see (Moyen et al., 2007). Briefly, leaf was excised from the stem of 2 month old plant and pulvinus fixed to the bottom of a $4 \mathrm{ml}$ plexiglas chamber filled with a buffered medium (10 mM MES, pH 5.5) containing $1 \mathrm{mM} \mathrm{NaCl}, 0.1 \mathrm{mM} \mathrm{KCl}$, and $0.1 \mathrm{mM} \mathrm{CaCl}$. The glass 
microelectrode was impaled into a motor cell of the abaxial ("extensor") half of the organ. Under these conditions, the resting transmembrane potential was in the range of -110 to -140 $\mathrm{mV}$, the calculated value from 39 assays being $-124 \pm 15 \mathrm{mV}$ (SD).

In order to observe $\mathrm{H}^{+}$excretion, $M$. pudica primary pulvini (400 mg) were excised from the leaves at 10.00 am borne on 2 months plants bearing 10 leaves, divided in transverse sections and treated following the same procedure previously described (Moyen et al., 2007): incubation medium composed of $0.50 \mathrm{mM} \mathrm{CaCl}_{2}, 0.25 \mathrm{mM} \mathrm{MgCl}_{2}$, variations of $\mathrm{pH}$ read on a pH-meter provided with combined electrodes (Futura micro-combination, Beckman Coulter) and linked to a potentiometric recorder. Compounds were added as indicated in the figures when the $\mathrm{pH}$ in the incubation medium reached 5.5. In order to quantify the amount of mobilized protons, titration was made on $2 \mathrm{ml}$ of the incubation medium at the optimum of the alcalinization (noted after the application of the compounds) with $\mathrm{NaOH}$ or $\mathrm{HCl}$ at $5.10^{-3}$ M. The experiments were repeated 3 times.

\subsection{Preparation and use of plasma membrane vesicles (PMVs)}

Purified PMVs were prepared by phase partitioning of microsomal fractions from the primary pulvini of M. pudica according to (Moyen et al., 2007) with some minor modifications. PMVs were frozen in liquid nitrogen and stored at $-80{ }^{\circ} \mathrm{C}$. They were put in the outside-out configuration by adding $0.05 \%$ brij in the assay medium. Vanadate-sensitive ATPase activity of the PMVs was measured as in a medium containing $40 \mu \mathrm{g}$ proteins and buffered with $50 \mathrm{mM}$ tris maleate at $\mathrm{pH}$ 6.9. In the 4 batches of vesicles used in this work, treatment with $0.25 \mathrm{mM}$ sodium orthovanadate showed that $60 \%$ of the enzyme activity can be attributed to plasma membrane functioning. Proton pumping was followed by the decrease of 9-aminoacridine absorbance at $495 \mathrm{~nm}$ in a medium containing $75 \mu \mathrm{g}$ proteins from frozenthawed PMV. The reaction started by addition of $3 \mathrm{mM} \mathrm{MgSO}_{4}$ into the medium buffered with $10 \mathrm{mM}$ tris maleate at $\mathrm{pH} 6.9$. 
2.5. Experimental procedure for observation of seismonastic reactions and dark-and light-induced reactions

The seismonastic reaction was observed on $M$. pudica seedlings bearing the first fully developed leaf. The seedlings were excised at 10.00 am with a sharp razor blade by cutting the hypocotyl $3 \mathrm{~cm}$ below the cotyledons. They were then dipped in distilled water in small plastic tubes for $4 \mathrm{~h}$ to allow post-harvest recovery. At this time (defined as " 0 "), distilled water was replaced by the tested compounds. Leaf position was determined by the angle $\alpha_{i}$ formed by the petiole and the line extended from the hypocotyl by means of a transparent protractor with a movable pointer (Figs. 1A,B). After measurement of the initial angle, the pulvini were stimulated by a touch applied on the abaxial half of the organs (Fig. 1C) at onehour intervals for $4 \mathrm{~h}$. The rapid drooping of the leaf achieved in about $2 \mathrm{~s}$ was monitored by measuring $10 \mathrm{sec}$ after the stimulation the variation of the angle $\alpha_{\mathrm{v}}$ (Fig. 1B). The experiments were repeated three times on ten seedlings, so that each experimental point represents observations on 30 motor organs.

The dark- and light-induced motor reactions of pulvinar leaflet in C. fasciculata were observed on 2 months old plants, bearing at least 10 leaves. After excision of the leaf, the cut petioles were dipped in distilled water for $1 \mathrm{~h}$ to allow post-harvest recovery and then transferred to test solutions. The leaves were put either in the dark in the middle of the photophase of the photoperiodic cycle, or in the light in the middle of the scotophase. The pulvinar movements resulting from the dark-induced (scotonasty) and the light-induced (photonasty) signals were monitored by measuring by homothety the distance between the leaflet tips with a calliper square (Fig. 1D). By this method, which allows rapid measurement, the leaf was not disturbed neither by a mechanical shock nor by a shading of the leaflets. This linear measurement was then converted into angular values as previously described 
(Bonnemain et al., 1978). The curves represent the mean values obtained from at least 3 separate experiments on eight individual leaves.

\subsection{Chemicals}

All chemicals were purchased from Sigma-Aldrich Chimie, Saint-Quentin-Fallavier, France. 2,4D was prepared in stock solutions at $10 \mathrm{mM}$ in absolute ethanol and used at a final concentration of $0.1 \mathrm{mM}$ (ethanol concentration 1\%) and lower. The synthesis of 2,4D-L-Lys and 2,4D-D-Lys, and other conjugates was previously reported (Chollet et al., 1997). Their structures are given in Table 1. These compounds were solubilized in $\mathrm{HCl}(6 \mathrm{M}, 1 \%$ of final volume of the incubation medium) and the $\mathrm{pH}$ of the medium has been readjusted to 5.5 with $\mathrm{NaOH}$. The stock solution was then diluted in buffers at the desired concentration. The same quantities of $\mathrm{HCl}$ and $\mathrm{NaOH}$ were added in the controls. The buffers used were $2.5 \mathrm{mM}$ HEPES $\left(\mathrm{pKa}_{2}=7.5\right)$ for experiments conducted at $\mathrm{pH} 7.5$ and $2.5 \mathrm{mM}$ MES $(\mathrm{pKa}=6.1)$ for experiments conducted at $\mathrm{pH} 5.5$ and 6.5. The $\mathrm{pH}$ of the solutions was adjusted with $0.1 \mathrm{M}$ $\mathrm{KOH}$ or $0.1 \mathrm{M}$ HCL. Control assays have shown that these buffered media did not affect significantly the pulvinar reactions. It was also checked that the various solvent concentrations present in the controls did not affect the processes studied to the final concentration used.

\subsection{Molecular descriptors calculation and statistical analyses}

Molecular descriptors of 2,4D-L-Lys and its analogues (Table 1) were predicted using ACD Percepta version 14 software. The descriptors considered had demonstrated their value in predicting the biological activity of a family of salicylic acid analogues in pulvinar cells of M. pudica (Rocher et al., 2017). The distribution coefficient D (typically used in the logarithmic form Log D) is a lipophilicity descriptor which is very important to consider for bioavailability and absorption studies of drugs and agrochemicals. It is a measure of the $\mathrm{pH}-$ 
dependant differential solubility of all species in the octanol/water system and can be defined as follows:

$$
\mathrm{D}=\frac{\sum[\text { Microspecies }]_{\mathrm{octanol}}}{\sum[\text { Microspecies }]_{\text {water }}}
$$

The distribution coefficient $\mathrm{D}$ should be used routinely for ionizable compounds in place of the partition coefficient $\mathrm{P}$, which can only be applied for neutral compounds and which leads to incorrect conclusions with ionisable compounds.

To investigate possible relationships between selected molecular descriptors and the effect of different amino acid conjugates in the $\mathrm{L}$ series on the movements of $C$. fasciculata leaflets, a Kendall correlation matrix was used because some descriptors did not follow a normal distribution and could have identical values in some series (see Table 1). Calculations and linear regressions were performed using XLStat 2020.2.3 software (Addinsoft, Paris, France, https://www.xlstat.com).

\section{Results}

\subsection{Metabolization assays of 2,4D-L-Lys}

Considering that 2,4D-L-Lys is more or less quickly cleaved into 2,4D and L-Lys according to the nature and functions of plant tissues (Delétage-Grandon et al. 2001; Wu et al. 2019), extraction processes and analyses were conducted as indicated in Material and Methods after two uptake durations (15 and $60 \mathrm{~min})$ of the conjugate by Mimosa pulvini. The records on chromatograms showed that 2,4D-L-Lys appears at 5.5 min retention time whereas 2,4D appears between 19.5 and $20 \mathrm{~min}$. The conjugate was detected in the extract after 15 $\min \left(11.1\right.$ nmoles. $\left.\mathrm{g}^{-1} \mathrm{FW}\right)$ and more clearly after $60 \mathrm{~min}\left(50\right.$ nmoles.g $\left.^{-1} \mathrm{FW}\right)$ incubation times (Fig. 2A). By contrast, no peak of 2,4D was detected until 60 min after treatment of the 
pulvini with 2,4D-L-Lys. In parallel, exogenously applied 2,4D was easily detected from pulvinar tissues (Fig. 2B).

\subsection{Effects of 2,4D-L-Lys on transmembrane potential difference and $p H$ of the} incubation medium

The addition of 10 and $100 \mu \mathrm{M}$ 2,4D-L-Lys (final concentration) to the bathing medium induced a hyperpolarization of the motor cell membrane ( -25 and $-47 \mathrm{mV}$ respectively) after a lag time of 8 and $4 \mathrm{~min}$ respectively (Table 2). The conjugate also induced a hyperpolarization with a similar latency and magnitude than the L-form. By contrast, L-Lys triggered a weak dose-dependent depolarization in a few seconds after its application.

Particular attention was paid to the PM-ATPase on account of several data showing that this enzyme is a target in the regulation of the motor cell-functioning as mentioned in the discussion. In a previous work (Otsiogo-Oyabi and Roblin, 1984), it has been shown that sections of primary pulvini spontaneously acidified their incubation medium as a result of proton pump activity. The time course of the $\mathrm{pH}$ variation recorded in the bathing medium of motor organ tissues was modified after addition of 2,4D-L-Lys at various concentrations (Fig. 3A), the threshold value being about $10 \mu \mathrm{M}$. At $100 \mu \mathrm{M}$, a pH rise started $20 \mathrm{~min}$ after the addition of the product, picked at 1 hour and decreased to the control level over a long time (more than 5 hours under our experimental conditions). 2,4D-D-Lys also induced a $\mathrm{pH}$ rise but the effect was lower (Fig. 3A). This is consistent with the difference of affinity of the amino-acid carrier system between the L-form and the D-form (Chollet et al., 1997). Comparatively, the addition of $100 \mu \mathrm{M}$ 2,4D modified the time course of the $\mathrm{pH}$ variation according to a biphasic pattern (Fig. 3B). First, it promoted a transient acidification of the medium after a latency of about $5 \mathrm{~min}$ and, secondly, it induced a rise in $\mathrm{pH}$ lasting for about 1 hour before a long-lasting return to the control level. In contrast, L-Lys showed a completely different effect in the $\mathrm{mM}$ range. At $1 \mathrm{mM}$, the amino acid induced a strong $\mathrm{pH}$ 
rise after a latency of $30 \mathrm{~min}$ that lasted a very long-time lapse to regain the control value (about $12 \mathrm{~h}$ under our experimental conditions). It has been verified that this effect on $\mathrm{pH}$ variation was not due to a modification in the buffering capacity of the compound.

In order to compare the direct effect of $10 \mu \mathrm{M} 2,4 \mathrm{D}-\mathrm{L}-\mathrm{Lys}$ on the PM-H ${ }^{+}$-ATPase activity with that of $10 \mu \mathrm{M}$ 2,4D already reported (Moyen et al., 2007), additional experiments have been carried out on PMVs purified from M. pudica pulvinar tissues. Proton pumping and vanadate-sensitive ATPase activity were not modified by the conjugate (Table 3).

\subsection{Effects of 2,4D-L-Lys on ion-driven osmocontractile cell reactions}

The seismonastic reaction of the primary pulvinus of $M$. pudica was inhibited by the conjugate in a dose-dependent manner for concentrations higher than $0.1 \mu \mathrm{M}$ (Fig. 4A). Indeed, calculations made $2 \mathrm{~h}$ after the start of the experiment gave inhibition values of about $10 \%$ at $0.1 \mu \mathrm{M}, 30 \%$ at $1 \mu \mathrm{M}, 50 \%$ at $10 \mu \mathrm{M}$ and $80 \%$ at $100 \mu \mathrm{M}$. The time courses also showed that the effect was clearly seen one hour after the addition of the compound in the test tube and that the complete effect took approximately $3 \mathrm{~h}$ to be achieved or almost achieved. It should be noted that the decreased value in angle variation resulted from an incomplete leaf sinking and an incomplete recovery which clearly took place at the highest concentrations as indicated by the increasing values of the initial position $\left(\alpha_{i}\right)$ in course of the experiment (Fig. 4B). The time course of 2,4D-L-Lys effect was not correlated with the absorption curve of the labelled product especially at its highest concentration. At time $1 \mathrm{~h}$, when 2,4D could not be detected in pulvinar tissues, the inhibition of leaf sinking reached about $60 \%$ of the whole effect noted at time $4 \mathrm{~h}$ while the uptake of the labelled conjugate was still limited to a minor part (less than 20\%) of its amount at the end of the experiment. Moreover, the inhibition of uptake (68\%) found at $\mathrm{pH} 5.5$ following a treatment with $10 \mu \mathrm{M}$ CCCP 
(Carbonyl cyanide m-chlorophenyl hydrazone) for $3 \mathrm{~h}$ indicated that a major part of the uptake was driven by an active process (Fig. 4A).

Cassia fasciculata leaflet model was used in subsequent assays. Compared with Mimosa, Cassia offers two advantages. First, it is devoid of seismonastic sensitivity and therefore easy to manipulate. Second, it exhibits larger responses to hormones and FC than $M$. pudica (Bonnemain et al., 1978). As shown in Fig. 5A, 2,4D-L-Lys modified the darkinduced closure of the leaflets when applied for $3 \mathrm{~h}$ before the dark signal. Movements were hindered in a dose-dependent manner at concentrations higher than $0.001 \mu \mathrm{M}(8 \%$ inhibition calculated $1 \mathrm{~h}$ after the dark signal), a nearly complete inhibition (93\%) being obtained at 1 $\mu \mathrm{M}$. An inhibition of $58 \%$ was calculated at $0.1 \mu \mathrm{M}$ and $32 \%$ at $0.01 \mu \mathrm{M}$. In contrast, $2,4 \mathrm{D}-\mathrm{L}-$ Lys promoted the light-induced opening of the leaflets but with a lower efficiency (Fig. 5B). Indeed, the threshold value was near $0.01 \mu \mathrm{M}(8 \%$ activation calculated $2 \mathrm{~h}$ after the light signal). At this time, the pulvinar reaction was promoted by $22 \%, 48 \%$ and $66 \%$ at $0.1,1$ and $10 \mu \mathrm{M}$ respectively. At this highest concentration, it should be stressed that the treated leaflets began their opening about $1 \mathrm{~h}$ before the light signal. This means that the light signal accelerated the cellular processes induced by the compound per se. This is corroborated by the observation of an opening reaction without light signal (Fig. 6A). However, in this case, the threshold value was $0.1 \mu \mathrm{M}$ (i.e. ten times higher than in light condition).

Considering that the dark-induced closure was dramatically sensitive to the conjugate, we chose this reaction to investigate the characteristics of 2,4D-L-Lys action. In the assays related to the effect of treatment duration, $0.5 \mu \mathrm{M}$ 2,4D-L-Lys was applied at 5, 15, 30 and $180 \mathrm{~min}$ before the onset of darkness. At the end of the incubation periods, the petiole tips were rinsed, and the leaves were transferred to vials containing $2.5 \mathrm{mM}$ MES at $\mathrm{pH} 5.5$. As shown in Fig. 7A, the inhibitory action increased when the incubation duration was lengthened. It should be stressed that an uptake period as short as 5 min produced a 
significant hindering of the reaction noted at time $1 \mathrm{~h}$ (17\% inhibition). The inhibitory effect triggered by a 15 min treatment was seen 30 min later and those triggered by a $30 \mathrm{~min}$ and 180 min treatment were detected 15 min after the dark signal. Applied at different $\mathrm{pH}$ in buffered media, $0.1 \mu \mathrm{M}$ 2,4D-L-Lys inhibited the leaflet closure at all the $\mathrm{pH}$ values tested and the inhibition ratio "treated sets / controls" was approximately similar from $\mathrm{pH} 5.5$ to 7.5 (Fig. 7B).

3.4. Comparison of the effects of several 2,4D-L-Lysine analogues on dark- and lightinduced leaflet movements

The compounds synthesized either with the L- form and the D- form of lysine showed a different efficiency. Indeed, the L-form of the compound inhibited more strongly the scotonastic reaction (Fig. 8A). Thus, used at 0.1 and $1 \mu \mathrm{M}$, an inhibition of $46 \%$ and $86 \%$ with L-form was respectively calculated whereas with the D- form at the same concentrations only inhibited the reaction by $3 \%$ and $60 \%$ respectively. A similar difference can also be seen on the photonastic reaction (Fig. 8B): activation of 50\% and $89 \%$ with the L-form, applied respectively at 0.1 and $1 \mu \mathrm{M} v s 21 \%$ and $52 \%$ with the D-form at the same concentrations. Modifications on the 2,4D moiety also induced variation on the efficiency (Fig. 8A, B). Indeed, the withdrawing of one chlorine both hindered the inhibition of the scotonastic reaction and the activation of the photonastic reaction. The presence of $\mathrm{NO}_{2}$ or $\mathrm{NH}_{2}$ groups in position 4 instead of a chlorine atom suppressed the efficiency of the molecule. The substitution of $\mathrm{Cl}$ in 2 position by a methyl group (MCPA-L-Lys) hindered the processes in a lower extent: scotonasty was inhibited by $43 \%$ and photonasty was activated by $64 \%$. Compared to MCPA-L-Lys, the assay with mecoprop-L-Lys also showed that a modification on the lateral chain (addition of a $\mathrm{CH}_{2}$ ) affected dramatically the efficiency of the conjugate. 


\section{Discussion}

\subsection{2,4D-L-Lys maintains the biological properties of 2,4D on pulvinar movements}

The molecular structure of synthetic compounds required for auxin activity was shown in pioneering works a long time ago: an unsaturated ring, a short acid side-chain and a particular arrangement between the ring and the side-chain (Leopold, 1955, Synerholm and Zimmerman, 1947). On the basis of these rules which have been never challenged to the best of our knowledge, synthetic auxins belonging to several chemical families (phenoxyalkanoic acids, pyridinecarboxylic acids, quinolinecarboxylic acids, a benzoic acid derivative) have a chain with only 1 to 3 carbons, in addition to the oxygen, between the unsaturated ring and the carboxyl group or even a carboxylic group grafted directly on the ring. Consequently, it seems unlikely that 2,4D-L-Lys with 7 carbons in addition to the oxygen and a nitrogen atom, between the aromatic ring and the $\alpha$-aminoacid function, instead of the carboxyl group, could exhibit functions mimicking auxinic activities.

Our study was made possible because the conjugate did not release 2,4D in detectable amount in pulvinar tissues for at least $1 \mathrm{~h}$ (Fig. 2) while a significant conjugate metabolism occurred in leaf tissues of Vicia faba (Delétage-Grandon et al., 2001) and in Ricinus cotyledons ( $\mathrm{Wu}$ et al., 2019). This discrepancy may be related to a different enzyme equipment between these three models. In a somewhat unexpected way, our data show that 2,4D-L-Lys exhibits almost exactly the same properties as $2,4 \mathrm{D}$ on pulvinar movements. Indeed the conjugate inhibited the shock-induced drooping movement of $M$. pudica plantlet leaves (Fig. 4A) and the dark-induced movement of $C$. fasciculata leaflets (Fig. 5A), and promoted the photonastic movement of these leaflets (Fig. 5B) in a similar range of concentrations and in similar time courses than with 2,4D (Bonmort and Roblin, 1996, Moyen et al., 2007). Therefore, the data suggest that conjugation does not modify the effects of 2,4D 
on ion and water fluxes underlying the seismonastic reaction and light- or dark-induced movements.

Some differences can be noted. At low concentrations in the incubation solution ( $0.1 \mu \mathrm{M}$ for seismonasty and $0.01 \mu \mathrm{M}$ for scotonasty), 2,4D-L-Lys exhibited a more potent effect (Fig. 4A and Fig. 5A, respectively) than 2,4D (Fig. 1A in Moyen et al, 2007 and Fig. 1A in Bonmort and Roblin, 1996, respectively). Concerning photonasty, at the highest concentrations used $(1$ and $10 \mu \mathrm{M})$, the conjugate triggered a faster reaction than $2,4 \mathrm{D}$ (compare Fig. 5B in this paper and Fig. 1B in Bonmort and Roblin, 1996). Notably, $10 \mu \mathrm{M}$ 2,4D-L-Lys induced leaflet aperture at time - 1 h, i.e. before the application of the light. This opening reaction without light signal (Fig. 6A) indicates that the conjugate triggers per se an influx of ions and water, as deduced from the mode of functioning of the pulvinar cells (Coté, 1995, Moran, 2007), the light signal superimposing its own influence on the process (Fig. 5B). Concerning seismonasty, while the decrease value in angle variation $\left(\alpha_{v}\right)$ results from an incomplete leaf sinking after a shock in presence of 2,4D (Moyen et al., 2007), this decrease results from both incomplete sinking and incomplete recovery in presence of 2,4D-L-Lys.

4.2. The fast foliar reactions triggered by 2,4D-L-Lys are not correlated with the time course of its active carrier-mediated uptake in pulvinar tissues

2,4D-L-Lys absorption by pulvinar tissues is an active carrier mediated mechanism (Fig. 4A). Its inhibition by $10 \mu \mathrm{M} \mathrm{CCCP} \mathrm{(approximately} \mathrm{70 \% )} \mathrm{is} \mathrm{higher} \mathrm{than} \mathrm{that} \mathrm{observed} \mathrm{in}$ the whole leaf tissues of $V . f a b a$ (approximately 20\%) but the active component of uptake occurs mainly in the veins which represent a very small compartment (Delétage-Grandon et al., 2001). Interestingly, the carrier-mediated system recognizing the amino-acid function discriminates positively the conjugate which is taken up by cotransport with protons. Indeed, at apoplasmic $\mathrm{pH}$ values, the rate of 2,4D- $\left({ }^{3} \mathrm{H}\right)$-L-Lys influx into the whole foliar tissues is 3 times faster than that of $\left({ }^{3} \mathrm{H}\right)$-L-Lys and, furthermore, the phloem transport of the conjugate to 
the root system is approximately 8 times higher than that of the amino acid under short time conditions (Fig. 7 and Table IV in Delétage-Grandon et al, 2001). Such selectivity also occurs in pulvinar tissues. At $100 \mu \mathrm{M}$ concentration, the conjugate triggers a $\mathrm{pH}$ rise of the incubation solution lasting a few hours (Fig. 3A) and exhibiting the characteristics of a symport with protons, i.e. a concomitant carrier-mediated uptake of 2,4D-L-Lys and $\mathrm{H}^{+}$ (Chollet et al., 1997, Delétage-Grandon et al., 2001) while $100 \mu \mathrm{M}$ Lys (Fig. 3B) and $100 \mu \mathrm{M}$ Gly (Fig. 4 in Otsiogo-Oyabi and Roblin, 1984) only cause a very weak effect. A concentration of amino acids at least 10 times higher is required to generate a clear $\mathrm{pH}$ rise of the incubating medium (Fig. 3B and Fig. 4 in Otsiogo-Oyabi and Roblin, 1984).

Under the same experimental conditions (products at $100 \mu \mathrm{M}$ concentration in the incubation solution, $\mathrm{pH} 5.5$ ), the amounts of 2,4D-L-Lys and 2,4D taken up by pulvinar tissues are approximately the same at time $1 \mathrm{~h}$ (Fig. 4A in this paper and Fig. 1B in Moyen et al, 2007). At this $\mathrm{pH}$ value, the herbicide is predicted to be completely under its anionic form using ACD Percepta v.14 software and, consequently, its carrier-mediated uptake should be a symport $2,4 \mathrm{D}-\mathrm{COO}^{-} / \mathrm{nH}^{+}$as it is the case for IAA-COO- (Felle et al., 1991). In this regard, similarly to the conjugate, $100 \mu \mathrm{M} 2,4 \mathrm{D}$ induces a $\mathrm{pH}$ rise of the incubating solution (Fig. 3B) but after a very short transient acidification when activation of the PM- $\mathrm{H}^{+}$-ATPase is the dominant process under our experimental conditions. While 2,4D absorption reaches a plateau after time 2h (Moyen et al., 2007), possibly because its protonophore effect at high concentrations, the amounts of 2,4D-L-Lys taken up by pulvini increase linearly for at least 4h. This uptake time course contrasts with the rapid foliar movements triggered by the conjugate. Indeed, its effect is achieved in major part or almost completely within the two first hours of treatment in the case of seismonasty (Fig. 4A) and scotonasty (Fig. 7A) whatever its concentration in the incubation medium (from 0.1 to $100 \mu \mathrm{M}$ ). Therefore, the early events generated by 2,4D-L-Lys need a special attention. 
4.3. The short lag times between 2,4D-L-Lys and 2,4D applications and hyperpolarization of motor cell plasma membrane are similar

The hormonal regulation of the $\mathrm{PM}-\mathrm{H}^{+}$-ATPase has been known for a long time. Half a century ago, auxin-induced growth of primary tissues was explained by the acid-growth theory which states that indolacetic acid (IAA) activates the $\mathrm{PM}-\mathrm{H}^{+}$-ATPase and therefore enhances proton efflux into the cell wall (Hager et al., 1971, Rayle and Cleland, 1970). Because the basipetal IAA transport takes place mainly in the cambial zone (Bourbouloux and Bonnemain, 1974), IAA also controls production and growth of secondary tissues in concert with other hormones. Since these pioneering works, many data from extensive studies have shown that IAA activates the $\mathrm{PM}-\mathrm{H}^{+}$-ATPase via $\mathrm{PM}$ receptors, such as the AUXIN BINDING PROTEIN 1 (ABP1) or auxin efflux carriers, and nuclear receptors, such as members of the TRANSPORT INHIBITOR RESPONSE1/AUXIN SIGNALING F-BOX (TIR1/AFB) auxin receptor family (Strader and Zhao, 2016). Both nuclear and PM receptor systems increase $\mathrm{H}^{+}$efflux, $\mathrm{K}^{+}$influx and water uptake but only the latter is involved in rapid auxin-induced responses (Dahlke et al., 2017). In addition, IAA and synthetic auxins like 2,4D may not bind to the same PM receptor (Kim et al., 2000) but the short delay between IAA or $2,4 \mathrm{D}$ applications and $\mathrm{H}^{+}$extrusion or membrane hyperpolarization is the same in coleoptile segments (Ruck et al., 1993).

By comparing the time course of the membrane potential changes of extensor motor cells following applications of 2,4D-L-Lys (this paper) and 2,4D (Moyen et al., 2007), it can be concluded that the conjugate induces the same modification as 2,4D in $M$. pudica, namely a hyperpolarization which occurs after the same lag times: 7-9 min at $10 \mu \mathrm{M}$ concentration in the incubation solution, about $4 \mathrm{~min}$ at $100 \mu \mathrm{M}$ concentration (Table 2). Therefore, these relatively short latencies observed after 2,4D and 2,4D-L-Lys application may suggest that the arrival of both compounds at the plasma membrane triggers a reaction chain needing a lapse 
of time to increase the transmembrane potential as it is the case after coleoptile treatments with IAA or 2,4D (Ruck et al., 1993). In this regard, IAA which mediates the activation of the PM- $\mathrm{H}^{+}$-ATPase in Arabidopsis hypocotyl via phosphorylation of its penultimate Thr residue induces a detectable increase of phosphorylation level of the enzyme after a lag time of about 5 min when applied at $10 \mu \mathrm{M}$ concentration and then hypocotyl elongation due to proton extrusion 5-10 min later (Takahashi et al., 2012). Additional data suggest that the nuclear auxin receptor TIR1/AFBs is not involved in this phosphorylation process. Therefore, the time course of the membrane hyperpolarization of extensor motor cells noted after 2,4D or 2,4D-L-Lys treatments is in agreement with a possible involvement of membrane receptors.

4.4. The similar or almost similar effects of 2,4D-L-Lys, 2,4D and FC on pulvinar movements are not correlated with their respective apparent ability to activate the PM- $\mathrm{H}^{+}$ATPase

Differences appear when comparing the early proton fluxes triggered by 2,4D and 2,4DL-Lys applications on $M$. pudica tissues. Firstly, the amplitude of the membrane hyperpolarization in extensor motor cells induced by 2,4D was the highest, especially at $100 \mu \mathrm{M}$ concentration in the incubation medium (Table 2). Secondly, using transverse sections of primary pulvini, the early phase of $\mathrm{pH}$ acidification of the bathing medium triggered by $100 \mu \mathrm{M} 2,4 \mathrm{D}$ application was no longer occurring with the conjugate at the same concentration (Fig. 3). Thirdly, when applied to plasma membrane vesicles purified from $M$. pudica pulvinar tissues, $10 \mu \mathrm{M}$ 2,4D-L-Lys failed to generate a moderate increase of proton pumping (Table 3) contrary to 2,4D under the same experimental conditions (Moyen et al., 2007). The proton influxes associated to 2,4D-L-Lys or 2,4D uptake in pulvinar cells (see above) must logically affect the transmembrane gradients generated by the proton pump. However, such fluxes do not occur using ISO vesicles and cannot alter proton pumping measurements. These data suggest that the herbicide and its conjugate do not possess the 
same ability to increase the $\mathrm{PM}-\mathrm{H}^{+}$-ATPase activity in pulvinar tissues although they act almost similarly on foliar movements.

The lack of apparent correlation between the measured stimulation of the PM$\mathrm{H}^{+}$ATPase and the pulvinar responses is also found when comparing the effects of $2,4 \mathrm{D}$ and 2,4D-L-Lys to those of FC. This fungal toxin locks the PM- $\mathrm{H}^{+}-\mathrm{ATPase} / 14-3-3$ protein complex in its phosphorylated C-terminus region, leading to a high and almost immediate proton pumping activity (Arango et al., 2003). Under our experimental conditions, FC is apparently the most efficient tool to hyperpolarize the plasma membrane of extensor motor cells, but it induces a lower effect on seismonastic reaction than the two xenobiotics. Indeed, at time $20 \mathrm{~min}, \mathrm{FC}, 2,4 \mathrm{D}$ and 2,4D-L-Lys at $10 \mu \mathrm{M}$ concentration triggered a hyperpolarization of $-60,-33$ and $-25 \mathrm{mV}$ respectively (Table 2) but $10 \mu \mathrm{M} \mathrm{FC}$ was required to exhibit the same early inhibitory action on seismonastic movements as the herbicide and the conjugate at $1 \mu \mathrm{M}$ concentration (compare Fig. 4A in this paper and Fig. 1A in Moyen et al, 2007). In addition, at low concentrations ( 0.1 and $1 \mu \mathrm{M}$ in the incubating solution), FC induced only a transient opening of $C$. fasciculata leaflets in dark conditions (chemionasty) which contrasts with the long-time reaction triggered by 0.1 and $1 \mu \mathrm{M} 2,4 \mathrm{D}-\mathrm{L}-\mathrm{Lys}$ (Fig. 6A and $B$ ).

Taken together, our data suggest that the mechanisms of the effect induced by $2,4 \mathrm{D}-\mathrm{L}$ Lys on pulvinar movements are more complex than only the activation of the motor cell PM$\mathrm{H}^{+}$-ATPase which is only in part supported at this stage of investigation. Given the structural changes of the aqueous vacuole membrane characterized by an increasing density of vacuolar $\mathrm{H}^{+}$-ATPases (V-ATPases) and aquaporins during maturation of aqueous motor cells (FleuratLessard et al., 1997), it can be suggested that the vacuolar proton pumps are internal targets of the 2,4D-L-Lys signalling. In addition, considering that the initial angle $\left(\alpha_{\mathrm{i}}\right)$ of $M$. pudica leaflets cannot be recovered after pulvinar stimulations in presence of the conjugate (Fig. 4B) 
and having in mind that the ABP1-IAA complex is indirectly implicated in microtubuli rearrangement and actin filament formation (Sauer and Kleine-Vehn, 2011), the effects of the conjugate on the arrangement of these microfilaments deserve to be studied using motor cell protoplasts of $M$. pudica.

4.5. In addition to the lipophilicity of the aromatic ring, a suitable orientation of the $\alpha$ amino-acid function is necessary for an optimal biological activity on pulvinar tissues

In agreement with the pioneering works already mentioned (Leopold, 1955, Synerholm and Zimmerman, 1947), the most active auxins of the phenoxyalkanoic acid family have a chain with only one carbon between the aromatic ring and the carboxyl group. Concerning $2,4 \mathrm{D}$, the carboxyl is almost or completely dissociated at apoplasmic $\mathrm{pH}$ values (from 4.5 to 6.5) (Felle, 2005) and acts as one of the ligands to receptors as it has been suggested a long time ago (Leopold, 1955). The elimination of the carboxyl dramatically affects its auxinic activity in addition to its phloem transport properties (Leopold, 1955, Neumann et al., 1985).

Our data from complementary investigations indicate that addition of a Lys moiety to the chain of an aromatic ring may not modify or may not greatly affect the recognition by auxinic receptors which trigger the ions (especially $\mathrm{K}^{+}$) and water fluxes known to be involved in motor cell swelling (Coté, 1995, Fleurat-Lessard et al., 1997, Moran, 2007, Scorza and Dornelas, 2011) provided that several physicochemical and structural parameters of the conjugates are satisfied. Considering the relationships between molecular descriptors of the various derivatives of the $\mathrm{L}$ series which have been synthesized and their effect on the movements of $C$. fasciculata leaflets (Table 4), halogen ratio value is the only parameter that has a statistically significant influence. The higher the halogen ratio value, the more pronounced the biological effect observed. This descriptor is defined as the ratio between the number of halogen atoms related to the total count of atoms in the molecule, excluding hydrogen atoms. Considering the amino acid conjugates of this study, the chlorine atoms are 
located only on the aromatic ring and it is therefore this part of the conjugate that will have the greatest influence on its biological activity. The influence of the lipophilicity of the whole molecule represented by $\log \mathrm{D}$ is not significant (Table 4). This is illustrated by the Mecoprop-L-Lys derivative which is the most lipophilic compound in this series $(\log \mathrm{D}=$ 1.72), but which has a lower activity than the MCPA-L-Lys derivative ( $\log D=1.49)$. In this case, the methyl group added to the side chain of MCPA dramatically reduced the biological effectiveness under our experimental conditions (Fig. 8). In addition to an aromatic ring with the two chlorine atoms in the optimum positions 2 and 4 (Moyen et al., 2007), the L-form of the $\alpha$-amino-acid function is required for an optimal biological activity on pulvinar tissues (Fig. 8). This might suggest that, despite the length of the chain, the dissociated carboxyl of the zwitterion is involved in the binding of 2,4D-L-Lys to some auxinic receptors.

\section{Conclusion}

Our data from $\mathrm{pH}$ and proton pumping measurements suggest that increasing the length of the chain of $2,4 \mathrm{D}$ and substitution of the carboxyl by an $\alpha$-amino acid function lead to a decrease of activation of the PM- $\mathrm{H}^{+}$-ATPase observed with 2,4D, and therefore of the ability to induce cellular growth in young tissues. This is well in agreement with the well-known rules established a long time ago (Leopold, 1955). Nevertheless, 2,4D-L-Lys triggers a moderate but early hyperpolarization of motor cell membrane with similar time course as 2,4D. As indicated previously (see $\S 4.4$ in the discussion), the measured values are the results of the conjugate-induced true hyperpolarization minus depolarization due to the concomitant influx of protons and 2,4D-L-Lys into the motor cells. Interestingly, 2,4D-L-Lys exhibits efficient biological properties on pulvinar cells in an almost similar way as the herbicide. These unexpected effects include seismonatic ( $M$. pudica), photonastic, scotonatic and chimionastic (C. fasciculata) foliar movements except some significant differences, such as 
(i) a more complex mechanism than the parent compound in seismonastic reactions; and (ii) a more efficient effect on dark-induced and light-induced movements at low and high concentrations, respectively. Various structural variations on the conjugate indicate that optimal biological activity requires, in addition to an optimal halogen ratio obtained by two chlorines atoms which must also be in positions 2 and 4 of the aromatic ring, a suitable orientation of the zwiterrion.

The positive effect of FC and IAA on motor cell swelling is generally explained by an activation of the $\mathrm{PM}-\mathrm{H}^{+}$-ATPase which triggers an influx of ions and possibly sugars energized either by the electrical component $\left(\mathrm{K}^{+}\right)$or the two components $\left(\mathrm{Cl}^{-}\right.$, sugars $)$of the proton motive force (see references in the introduction and discussion). Our data suggest that the efficient action of 2,4D-L-Lys on ion-driven reactions involves complementary mechanisms. Indeed, despite the sole evidence (electrophysiology data) that the conjugate acts as an activator of this proton pump, it generates a much more potent effect than $\mathrm{FC}$ on touch induced movements and at low concentrations, is more efficient than the fungal toxin to induce $C$. fasciculata leaflet opening in dark condition. As already mentioned, these apparent discrepancies guide future investigations in two directions, namely the study of the effect of 2,4D-L-Lys on (i) the arrangement of the motor cell cytoskeleton elements; and (ii) on the activity of the V-ATPase and V-PPase of vacuolar membrane. Indeed, as these pumps energized various solute transports (Martinoia et al., 2012), they must act in combination with the PM- $\mathrm{H}^{+}$-ATPase to regulate motor cell swelling, as suggested before (Scorza and Dornelas, 2011) but experimental data are lacking. While numerous physiological and then molecular studies have been carried out on $\mathrm{PM}-\mathrm{H}^{+}$-ATPase, the effect of natural and synthetic auxins on the vacuolar pump activity of motor cell aqueous vacuoles has paradoxically not given rise to any study to the best of our knowledge. 


\section{Acknowledgements}

The authors acknowledge financial support from the European Union (ERDF) and "Région Nouvelle Aquitaine".

\section{References}

Arango, M., Gevaudant, F., Oufattole, M., Boutry, M., 2003. The plasma membrane proton pump ATPase: the significance of gene subfamilies. Planta 216, 355-365. https://doi.org/10.1007/s00425-002-0856-8

Bonmort, J., Roblin, G., 1996. Effect of 2,4-dichlorophenoxyacetic acid on the dark- and light-induced pulvinar movements in Cassia fasciculata Michx. Plant Growth Regul. 19, 61-65. https://doi.org/10.1007/bf00024403

Bonnemain, J.L., Roblin, G., Gaillochet, J., Fleurat-Lessard, P., 1978. Effets de l'acide abscissique et de la fusicoccine sur les reactions motrices des pulvinus du Cassia fasciculata Michx. et du Mimosa pudica L. C. r. hebd. séances Acad. sci. série D 286, 1681-1686. https://doi.org/

Bourbouloux, A., Bonnemain, J.L., 1974. Transport, distribution and metabolism of auxin in Vicia faba L roots after application of C-14 IAA or H-3 IAA to apical bud. Planta 119, 169-182. https://doi.org/10.1007/bf00429042

Chollet, J.F., Delétage, C., Faucher, M., Miginiac, L., Bonnemain, J.L., 1997. Synthesis and structureactivity relationships of some pesticides with an alpha-amino acid function. Biochim. Biophys. Acta 1336, 331341. https://doi.org/10.1016/s0304-4165(97)00041-x

Coté, G.G., 1995. Signal transduction in leaf movement. Plant Physiol. 109, 729-734. https://doi.org/10.1104/pp.109.3.729

Dahlke, R.I., Fraas, S., Ullrich, K.K., Heinemann, K., Romeiks, M., Rickmeyer, T., Klebe, G., Palme, K., Luethen, H., Steffens, B., 2017. Protoplast swelling and hypocotyl growth depend on different auxin signaling pathways. Plant Physiol. 175, 982-994. https://doi.org/10.1104/pp.17.00733

Delétage-Grandon, C., Chollet, J.F., Faucher, M., Rocher, F., Komor, E., Bonnemain, J.L., 2001. Carriermediated uptake and phloem systemy of a 350-dalton chlorinated xenobiotic with an alpha-amino acid function. Plant Physiol. 125, 1620-1632. https://doi.org/10.1104/pp.125.4.1620

Dufaud, A., Chollet, J.F., Rudelle, J., Miginiac, L., Bonnemain, J.L., 1994. Derivatives of pesticides with an alpha-amino acid function: synthesis and effect on threonine uptake. Pestic. Sci. 41, 297-304. https://doi.org/10.1002/ps.2780410403

Éverat-Bourbouloux, A., Fleurat-Lessard, P., Roblin, G., 1990. Comparative effects of indole-3-acetic acid, abscisic acid, gibberellic acid and 6-benzylaminopurine on the dark-induced and light-induced pulvinar movements in Cassia fasciculata Michx. J. Exp. Bot. 41, 315-324. https://doi.org/10.1093/jxb/41.3.315

Felle, H., Peters, W., Palme, K., 1991. The electrical response of maize to auxins. Biochim. Biophys. Acta 1064, 199-204. https://doi.org/10.1016/0005-2736(91)90302-o

Felle, H.H., 2005. $\mathrm{pH}$ regulation in anoxic plants. Ann. Bot. 96, 519-532. https://doi.org/10.1093/aob/mci207

Fleurat-Lessard, P., Bouché-Pillon, S., Leloup, C., Bonnemain, J.L., 1997. Distribution and activity of the plasma membrane $\mathrm{H}^{+}$-ATPase in Mimosa pudica $\mathrm{L}$ in relation to ionic fluxes and leaf movements. Plant Physiol. 113, 747-754. https://doi.org/10.1104/pp.113.3.747 
Fleurat-Lessard, P., Frangne, N., Maeshima, M., Ratajczak, R., Bonnemain, J.L., Martinoia, E., 1997. Increased expression of vacuolar aquaporin and $\mathrm{H}^{+}$-ATPase related to motor cell function in Mimosa pudica L. Plant Physiol. 114, 827-834. https://doi.org/10.1104/pp.114.3.827

Fleurat-Lessard, P., Schmit, A.C., Vantard, M., Stoeckel, H., Roblin, G., 1993. Characterization and immunocytochemical distribution of microtubules and F-actin filaments in protoplasts of Mimosa pudica motor cells. Plant Physiol. Biochem. 31, 757-764. https://doi.org/

Hager, A., 2003. Role of the plasma membrane $\mathrm{H}^{+}$-ATPase in auxin-induced elongation growth: historical and new aspects. J. Plant Res. 116, 483-505. https://doi.org/10.1007/s10265-003-0110-x

Hager, A., Menzel, H., Krauss, A., 1971. Experiments and hypothesis concerning primary action of auxin in elongation growth. Planta 100, 47-75. https://doi.org/10.1007/bf00386886

Hayashi, Y., Takahashi, K., Inoue, S., Kinoshita, T., 2014. Abscisic acid suppresses hypocotyl elongation by dephosphorylating plasma membrane $\mathrm{H}^{+}$-ATPase in Arabidopsis thaliana. Plant Cell Physiol. 55, 845-853. https://doi.org/10.1093/pcp/pcu028

Kim, Y.S., Kim, D., Jung, J., 2000. Two isoforms of soluble auxin receptor in rice (Oryza sativa L.) plants: Binding property for auxin and interaction with plasma membrane $\mathrm{H}^{+}$-ATPase. Plant Growth Regul. 32, 143-150. https://doi.org/10.1023/a:1010745310101

Leopold, A.C., 1955. Auxins and plant growth. University of California Press, Berkeley and Los Angeles.

Martinoia, E., Meyer, S., De Angeli, A., Nagy, R., 2012. Vacuolar transporters in their physiological context. In: Merchant, S.S. (Ed.), Annual Review of Plant Biology, Vol 63. Annual Reviews, Palo Alto, pp. 183-213.

Moran, N., 2007. Osmoregulation of leaf motor cells. FEBS Lett. 581, 2337-2347. https://doi.org/10.1016/j.febslet.2007.04.002

Moyen, C., Bonmort, J., Roblin, G., 2007. Membrane effects of 2,4-dichlorophenoxyacetic acid in motor cells of Mimosa pudica L. Plant Physiol. Biochem. 45, 420-426. https://doi.org/10.1016/j.plaphy.2007.03.030

Neumann, S., Grimm, E., Jacob, F., 1985. Transport of xenobiotics in higher plants.1. Structural prerequisites for translocation in the phloem. Biochem. Physiol. Pflanz. 180, 257-268. https://doi.org/10.1016/s0015-3796(85)80001-9

Otsiogo-Oyabi, H., Roblin, G., 1984. Effects of glycine on dark-induced and light-induced pulvinar movements and modifications of proton fluxes in the pulvinus of Mimosa pudica during glycine uptake. Planta 161, 404-408. https://doi.org/10.1007/bf00394570

Pietruszka, M., Lewicka, S., 2007. Anisotropic plant growth due to phototropism. J. Math. Biol. 54, 4555. https://doi.org/10.1007/s00285-006-0045-7

Rayle, D., Cleland, R., 1970. Enhancement of wall loosening and elongation by acid solutions. Plant Physiol. 46, 250-253. https://doi.org/10.1104/pp.46.2.250

Roblin, G., 1976. Experimental analysis of seismonastic movement in sensitive plant. Nature 261, 437438. https://doi.org/10.1038/261437a0

Roblin, G., 1977. Endogenous rhythms in Mimosa pudica leaf movements. J. Interdiscipl. Cycle Res. 8, 89-109. https://doi.org/10.1080/09291017709359549

Rocher, F., Roblin, G., Chollet, J.F., 2017. Modifications of the chemical structure of phenolics differentially affect physiological activities in pulvinar cells of Mimosa pudica L. II. Influence of various molecular properties in relation to membrane transport. Environ. Sci. Pollut. Res. 24, 6910-6922. https://doi.org/10.1007/s11356-016-6048-z 
Ruck, A., Palme, K., Venis, M.A., Napier, R.M., Felle, R.H., 1993. Patch-clamp analysis establishes a role for an auxin-binding protein in the auxin stimulation of plasma membrane current in Zea mays protoplasts. Plant J. 4, 41-46. https://doi.org/10.1046/j.1365-313X.1993.04010041.X

Sauer, M., Kleine-Vehn, J., 2011. Auxin binding protein1: the outsider. Plant Cell 23, 2033-2043. https://doi.org/10.1105/tpc.111.087064

Scorza, L.C.T., Dornelas, M.C., 2011. Plants on the move: towards common mechanisms governing mechanically-induced plant movements. Plant Signal. Behav. 6, 1979-1986. https://doi.org/10.4161/psb.6.12.18192

Strader, L.C., Zhao, Y., 2016. Auxin perception and downstream events. Curr. Opin. Plant Biol. 33, 8-14. https://doi.org/10.1016/j.pbi.2016.04.004

Synerholm, M.E., Zimmerman, P., 1947. Preparation of a series of omega-(2,4-dichlorophenoxy) aliphatic acids and some related compounds with a consideration of their biochemical role as plant growth regulators. Contr. Boyce Thompson Inst. 14, 369-382. https://doi.org/

Takahashi, K., Hayashi, K.-i., Kinoshita, T., 2012. Auxin activates the plasma membrane $\mathrm{H}^{+}$-ATPase by phosphorylation during hypocotyl elongation in Arabidopsis. Plant Physiol. 159, 632-641. https://doi.org/10.1104/pp.112.196428

Temmei, Y., Uchida, S., Hoshino, D., Kanzawa, N., Kuwahara, M., Sasaki, S., Tsuchiya, T., 2005. Water channel activities of Mimosa pudica plasma membrane intrinsic proteins are regulated by direct interaction and phosphorylation. FEBS Lett. 579, 4417-4422. https://doi.org/10.1016/j.febslet.2005.06.082

Volkov, A.G., Foster, J.C., Ashby, T.A., Walker, R.K., Johnson, J.A., Markin, V.S., 2010. Mimosa pudica: Electrical and mechanical stimulation of plant movements. Plant, Cell Environ. 33, 163-173. https://doi.org/10.1111/j.1365-3040.2009.02066.x

Wu, H., Xu, H., Marivingt-Mounir, C., Bonnemain, J.-L., Chollet, J.-F., 2019. Vectorizing agrochemicals: enhancing bioavailability via carrier-mediated transport. Pest Manage. Sci. 75, 1507-1516. https://doi.org/10.1002/ps.5298

Yao, H., Xu, Q., Yuan, M., 2008. Actin dynamics mediates the changes of calcium level during the pulvinus movement of Mimosa pudica. Plant Signal. Behav. 3, 954-960. https://doi.org/10.4161/psb.6709 
Table 1. Structures of Xenobiotic-Lysine derivatives and their molecular descriptors. MW: Molecular Weight; PSA: Polar Surface Area; FRB: Free Rotatable Bond; HBD: Hydrogen Bond Donors; HBA: Hydrogen Bond Acceptors. All descriptors were computed using ACD Percepta v.14 software. The names in square brackets are the abbreviations used in the text to refer to these products.

\begin{tabular}{|c|c|c|c|c|c|c|c|c|c|}
\hline Xenobiotic & $\mathbf{X}$ & $\mathbf{Y}$ & $\mathbf{Z}$ & MW & $\begin{array}{c}\log D \\
\text { pH } 5.5 \\
\text { pH } 6.5 \\
\text { pH } 7.5\end{array}$ & $\begin{array}{c}\text { Halogen } \\
\text { ratio }\end{array}$ & PSA & FRB & $\begin{array}{l}\text { HBD } \\
+ \\
\text { HBA }\end{array}$ \\
\hline $\begin{array}{l}\text { (2,4-dichlorophenoxy)acetic acid - L(D)- } \\
\text { Lysine } \\
\text { [2,4D-L-Lys] ; [2,4D-D-Lys }]\end{array}$ & $\mathrm{Cl}$ & $\mathrm{Cl}$ & $\mathrm{H}$ & 349.21 & 1.48 & 0.09 & 101.65 & 9 & 10 \\
\hline $\begin{array}{l}\text { 4-Chlorophenoxy)acetic acid - L-Lysine } \\
\text { [4Cl-PhenOxAc-L-Lys] }\end{array}$ & $\mathrm{Cl}$ & $\mathrm{H}$ & $\mathrm{H}$ & 314.76 & 0.98 & 0.05 & 101.65 & 9 & 10 \\
\hline $\begin{array}{l}\text { Phenoxyacetic acid - L-Lysine } \\
\text { [PhenOxAc-L-Lys] }\end{array}$ & $\mathrm{H}$ & $\mathrm{H}$ & $\mathrm{H}$ & 280.32 & 0.46 & 0.00 & 101.65 & 9 & 10 \\
\hline $\begin{array}{l}\text { (4-Nitrophenoxy)acetic acid - L-Lysine } \\
{\left[4 \mathrm{NO}_{2} \text {-PhenOxAc-L-Lys] }\right.}\end{array}$ & $\mathrm{NO}_{2}$ & $\mathrm{H}$ & $\mathrm{H}$ & 325.32 & 0.35 & 0.00 & 150.48 & 10 & 13 \\
\hline $\begin{array}{l}\text { (4-Aminophenoxy)acetic acid - L-Lysine } \\
\text { [4NH2-PhenOxAc-L-Lys] }\end{array}$ & $\mathrm{NH}_{2}$ & $\mathrm{H}$ & $\mathrm{H}$ & 295.33 & $\begin{array}{r}-0.63 \\
-0.49 \\
-0.47\end{array}$ & 0.00 & 127.67 & 9 & 13 \\
\hline $\begin{array}{l}\text { (4-Chloro-2-methylphenoxy)acetic acid - L- } \\
\text { Lysine } \\
\text { [MCPA-L-Lys] }\end{array}$ & $\mathrm{Cl}$ & $\mathrm{CH}_{3}$ & $\mathrm{H}$ & 328.79 & 1.49 & 0.05 & 101.65 & 9 & 10 \\
\hline $\begin{array}{l}\text { 2-(4-Chloro-2-methylphenoxy)propanoic } \\
\text { acid - L-Lysine } \\
\text { [Mecoprop-L-Lys] }\end{array}$ & $\mathrm{Cl}$ & $\mathrm{CH}_{3}$ & $\mathrm{CH}_{3}$ & 342.82 & 1.72 & 0.04 & 101.65 & 9 & 10 \\
\hline (2,4-dichlorophenoxy)acetic acid $[2,4-D]$ & & & & 221.04 & $\begin{array}{r}0.32 \\
-0.58 \\
-1.12\end{array}$ & 0.15 & 46.53 & 3 & 4 \\
\hline L-Lysine [L-Lys] & & & & 146.19 & $\begin{array}{l}-2.27 \\
-2.26 \\
-2.20\end{array}$ & 0.00 & 89.34 & 5 & 9 \\
\hline
\end{tabular}


Table 2. Modification of the bioelectrical transmembrane potential of the pulvinar motor cell of $M$. pudica by the different compounds at various concentrations. Measurements of $\Delta \Psi$ were made 20 min after addition of the compounds (- indicates a hyperpolarization and $+\mathrm{a}$ depolarization). The resting transmembrane potential was $-124 \pm 15 \mathrm{mV}(\mathrm{n}=39)$.

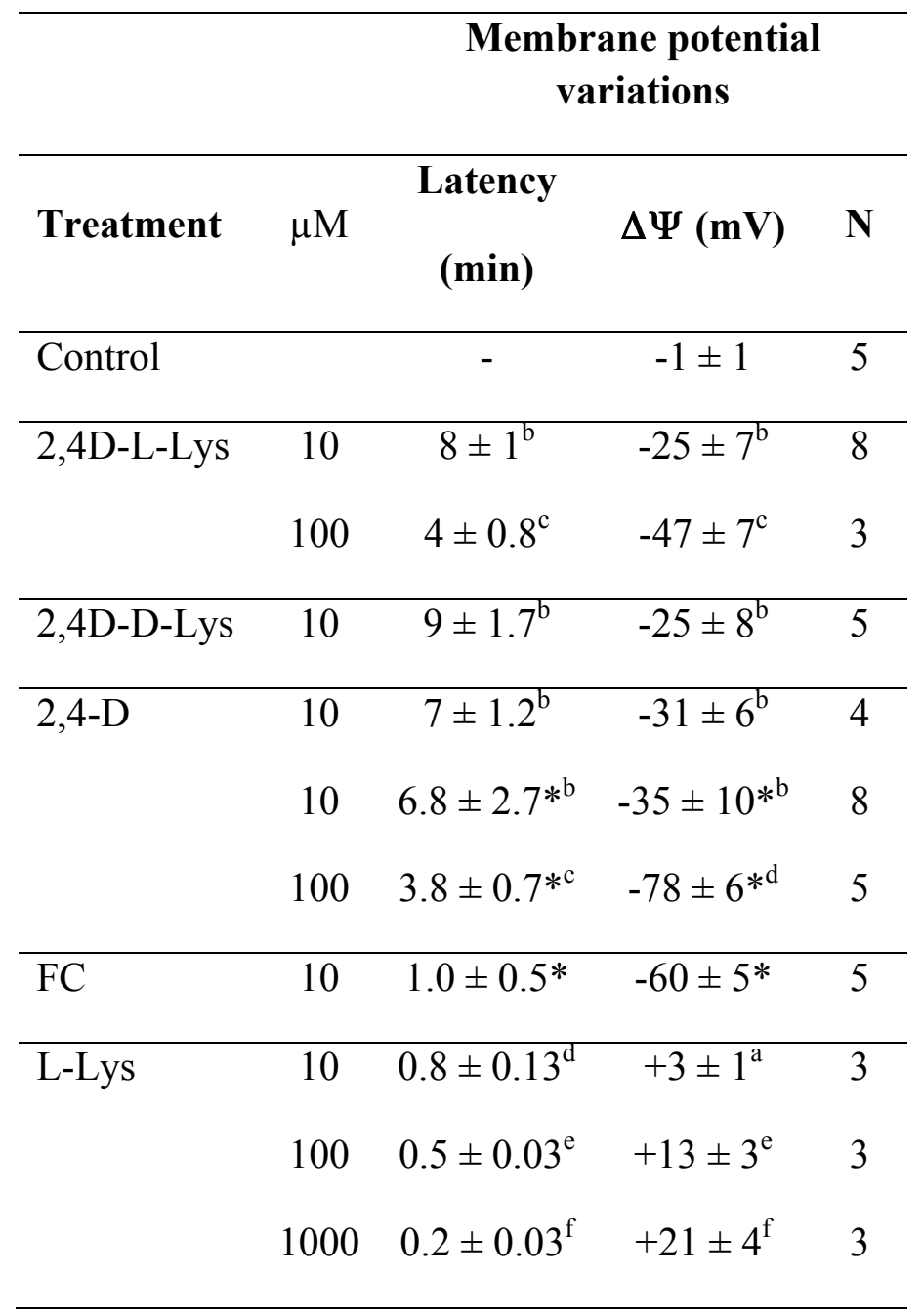

Values represent the means \pm SD. Superscript letters indicate significant differences at the 5\% probability level by Student-Fisher t test $(b, c, d, e, f)$ or values not significantly different from the control $(a)$. N: number of assays. * data reported from Moyen et al., 2007. 
Table 3. Modifications of net proton movement (measured by absorbance variation from the control absorbance at $495 \mathrm{~nm}$ ) and vanadate-sensitive ATPase activity in plasma membranes vesicles purified from $M$. pudica pulvini treated with 2,4D-L-Lys at $10 \mu \mathrm{M}$, lysine at $1000 \mu \mathrm{M}$ and vanadate at $25 \mu \mathrm{M}$.

\begin{tabular}{|c|c|c|c|}
\hline & $\begin{array}{c}\text { Concentration } \\
\qquad(\mu \mathrm{M})\end{array}$ & $\begin{array}{l}\text { Absorbance variation } \\
\left(\text { unit } \operatorname{mg~prot~}^{-1} \min ^{-1} \text { ) }\right.\end{array}$ & $\begin{array}{c}\text { Vanadate-sensitive ATP-ase } \\
\text { activity } \\
\left(\text { nmol Pi mg prot }{ }^{-1} \text { min }^{-1}\right)\end{array}$ \\
\hline Control & - & $0.335 \pm 0.003(12)^{\mathrm{a}}$ & $341 \pm 27(16)^{\mathrm{a}}$ \\
\hline Control-HCl & - & $0.333 \pm 0.004(7)^{\mathrm{a}}$ & $336 \pm 34(12)^{\mathrm{a}}$ \\
\hline 2,4D-L-Lys & 10 & $0.348 \pm 0.009(7)^{\mathrm{a}}$ & $327 \pm 40(12)^{\mathrm{a}}$ \\
\hline L-Lysine & 1000 & $0.352 \pm 0.011(4)^{\mathrm{a}}$ & $347 \pm 9(6)^{\mathrm{a}}$ \\
\hline Vanadate & 25 & $0.160 \pm 0.06(4)^{\mathrm{b}}$ & $158 \pm 2(4)^{\mathrm{c}}$ \\
\hline
\end{tabular}

Values are means $\pm \mathrm{SD}$ (number of assays). Superscript letters indicate significant differences at the $5 \%$ probability level by Student-Fisher $t$ test $(b-c)$ or values not significantly different from the control $(a)$. 
Table 4. Kendall correlation matrix related to the biological effects of L-amino acid conjugates reported in Figure 8. The molecular descriptors of the tested compounds are listed in Table 1. The correlation coefficients are provided along with the associated $p$ values (in parentheses).

\begin{tabular}{|c|c|c|c|c|c|c|}
\hline $\begin{array}{r}\text { Molecular } \\
\text { descriptors }\end{array}$ & $\begin{array}{l}\text { Molecular } \\
\text { Weight }\end{array}$ & $\begin{array}{c}\log D \\
(\text { pH 5.5) }\end{array}$ & $\begin{array}{l}\text { Halogen } \\
\text { ratio }\end{array}$ & $\begin{array}{c}\text { Polar } \\
\text { Surface } \\
\text { Area }\end{array}$ & $\begin{array}{c}\text { Free } \\
\text { Rotatable } \\
\text { Bonds }\end{array}$ & $\begin{array}{l}\text { Hydrogen Bond } \\
\text { Donors + Hydrogen } \\
\text { Bond Acceptors }\end{array}$ \\
\hline $\begin{array}{c}\text { Leaflet angle } \\
\text { (dark) }\end{array}$ & $\begin{array}{c}0.429 \\
(0.230)\end{array}$ & $\begin{array}{c}0.524 \\
(0.133) \\
\end{array}$ & $\begin{array}{c}0,794 \\
(0.026) \\
\end{array}$ & $\begin{array}{l}-0.592 \\
(0.128)\end{array}$ & $\begin{array}{l}-0.356 \\
(0.453)\end{array}$ & $\begin{array}{l}-0.690 \\
(0.081)\end{array}$ \\
\hline $\begin{array}{c}\text { Leaflet angle } \\
\text { (light) }\end{array}$ & $\begin{array}{c}0.488 \\
(0.172) \\
\end{array}$ & $\begin{array}{c}0.390 \\
(0.288) \\
\end{array}$ & $\begin{array}{c}0,868 \\
(0.016) \\
\end{array}$ & $\begin{array}{l}-0.539 \\
(0.179)\end{array}$ & $\begin{array}{l}-0.548 \\
(0.207)\end{array}$ & $\begin{array}{l}-0.495 \\
(0.241)\end{array}$ \\
\hline
\end{tabular}




\section{Figure legends}

Figure 1. Schematic representation of the plant models used. A, B: Drooping movement effected by the primary pulvinus of the $M$. pudica plantlet leaf following a mechanical shock applied on the extensor part of the organ $(\mathbf{C}) ; \alpha_{\mathrm{i}}$ : initial angle formed by the petiole and the line extended from the hypocotyl; $\alpha_{\mathrm{v}}$ : angle variation. D: Movements effected by the pulvinated leaves of $C$. fasciculata in response to dark and light signals and to compounds without light signal. They were monitored by measuring by homothety the distance between the leaflet tips with a calliper square and this linear measurement was then converted into angular values.

Figure 2. Study of 2,4D-L-Lys metabolism in $M$. pudica pulvini. A: when present, 2,4D-L-Lys appears on the first part of the chromatogram $(\mathrm{Rt}=5.5 \mathrm{~min}) .1$ : control, $\mathrm{t}=0$ (beginning of the experiment). 2,4D-L-Lys was detected after $15 \mathrm{~min}$ (2) and $60 \mathrm{~min}$ (3) incubation times. 2,4D-L-Lys standard was added to the $60 \mathrm{~min}$ extract to confirm its presence (4). B: when present, 2,4D appears at the end of the chromatogram ( $\mathrm{Rt}=19.7 \mathrm{~min})$. 5: $2,4 \mathrm{D}$ standard was added to the 0 min extract $(1$; control) to confirm its retention time in this matrix. Noteworthy, there was no trace of 2,4D after $15 \mathrm{~min}$ (2) and $60 \mathrm{~min}$ (3) incubation times with 2,4D-L-Lys. The same assay conducted with 2,4D alone at $100 \mu \mathrm{M}$ concentration on pulvini extracted after $180 \mathrm{~min}$ incubation showed the presence of 2,4D (6).

Figure 3: Representative time courses of $\mathrm{pH}$ variations monitored in the bathing medium of $M$. pudica pulvinar tissues induced by various compound additions (arrow heads). A: $2,4 \mathrm{D}$-L-Lys at 10,50 and $100 \mu \mathrm{M}$ and by $2,4 \mathrm{D}-\mathrm{D}$-Lys at $100 \mu \mathrm{M}$. B: $2,4 \mathrm{D}$ at $100 \mu \mathrm{M}$ and lysine at 100 and $1000 \mu \mathrm{M}$. These experiments were repeated three times with similar results.

Figure 4: Effect of 2,4D-L-Lys on the drooping movement of $M$. pudica plantlet leaves induced by a touch applied each hour on the extensor part. A: Time course of the inhibition of the seismonastic pulvinar osmocontractile reaction following treatment with 2,4D-L-Lys (arrow head) at various concentrations as indicated in $\mu \mathrm{M}$. In bold line, time course of the amount of labelled compound absorbed by the pulvinar tissues incubating in a medium containing $100 \mu \mathrm{M} 2,4 \mathrm{D}-{ }^{3} \mathrm{H}-\mathrm{L}-\mathrm{Lys}$ (Mean $\pm \mathrm{SD}, \mathrm{n}=3$ ). B: Time course of the initial angle $\left(\alpha_{\mathrm{i}}\right)$ recovered after pulvinar stimulation following treatment with 2,4D-L-Lys at various concentrations as indicated in $\mu \mathrm{M}$. Each measurement was done just after $\left(\mathbf{A}, \alpha_{v}\right)$ and just before $\left(B, \alpha_{i}\right)$ the touch. Mean $\pm \mathrm{SE}, \mathrm{n}=30$.

Figure 5: Effect of 2,4D-L-Lys on leaflet movements of C. fasciculata. Influence of various concentrations of the conjugate on the time course of the dark-induced (A) and lightinduced (B) reactions. The conjugate was applied for $180 \mathrm{~min}$ before the onset of the dark- or light period. Dark: the light was switched off in the middle of the photophase. Light: the light was switched on in the middle of the nyctophase of the photoperiodic cycle. Vertical bars represent $\mathrm{SE}$ of the mean. $\mathrm{n}=24$.

Figure 6: Comparison of the effects of 2,4D-L-Lys and fusicoccin on leaflet movements of $C$. fasciculata. Influence of various concentrations of 2,4D-L-Lys (A) or fusicoccin [FC] (B, from Bonnemain et al, 1978) on the time course of the leaflet movements without external signal (dark condition). Vertical bars represent SE of the mean, $n=24$ (A) or $\mathrm{n}=8(\mathrm{~B})$. 
Figure 7: Effect of 2,4D-L-Lys treatments applied before the dark signal on the scotonastic closure of $C$. fasciculata leaflets. A: Effect of the treatment duration with $0.5 \mu \mathrm{M}$ 2,4D-L-Lys applied at 5, 15, 30 and $180 \mathrm{~min}$ before this signal. B: Effect of $0.1 \mu \mathrm{M} 2,4 \mathrm{D}-\mathrm{L}-$ Lys solution (black columns) at various $\mathrm{pH}$ values on angle variation $\left(\alpha_{\mathrm{v}}\right)$ compared to 2.5 $\mathrm{mM}$ buffer solutions used for dilution of the compound (white columns). 2,4D-L-Lys was applied for 180 min before the dark signal. Angles were calculated $1 \mathrm{~h}$ after the start of the dark period. Vertical bars represent SE of the mean; $n=24$.

Figure 8. Comparative effects of 2,4D-L-Lys derivatives on dark-induced (A) and lightinduced (B) movements of C. fasciculata leaflets. Compounds were applied for $180 \mathrm{~min}$ before the onset of the dark- and light period. Angles were calculated $1 \mathrm{~h}$ after the start of the dark and light signals. See Table 1 for complete formula. White columns: $0.1 \mu \mathrm{M}$, grey columns: $1 \mu \mathrm{M}$. Vertical bars represent SE of the mean; $n=24$. 

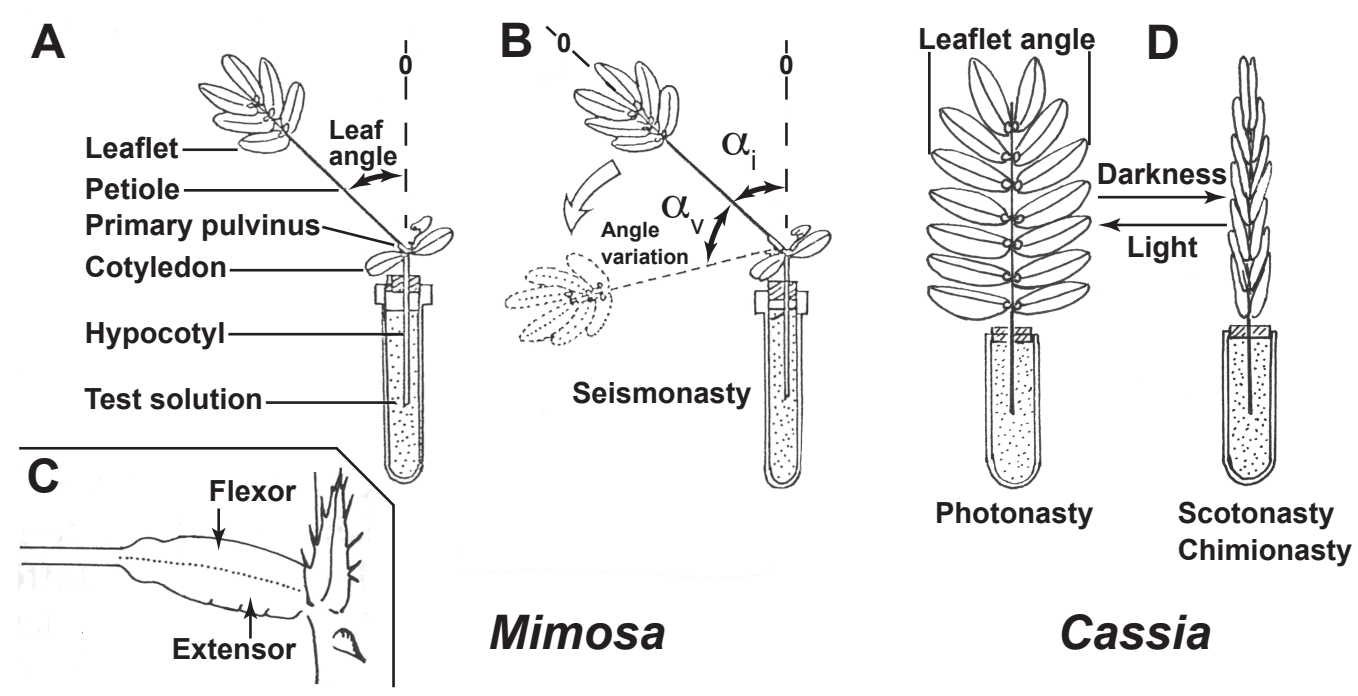

Figure 1. Schematic representation of the plant models used. A, B: Drooping movement effected by the primary pulvinus of the $M$. pudica plantlet leaf following a mechanical shock applied on the extensor part of the organ $(\mathbf{C}) ; \alpha_{\mathrm{i}}$ : initial angle formed by the petiole and the line extended from the hypocotyl; $\alpha_{\mathrm{v}}$ : angle variation. D: Movements effected by the pulvinated leaves of $C$. fasciculata in response to dark and light signals and to compounds without light signal. They were monitored by measuring by homothety the distance between the leaflet tips with a calliper square and this linear measurement was then converted into angular values. 

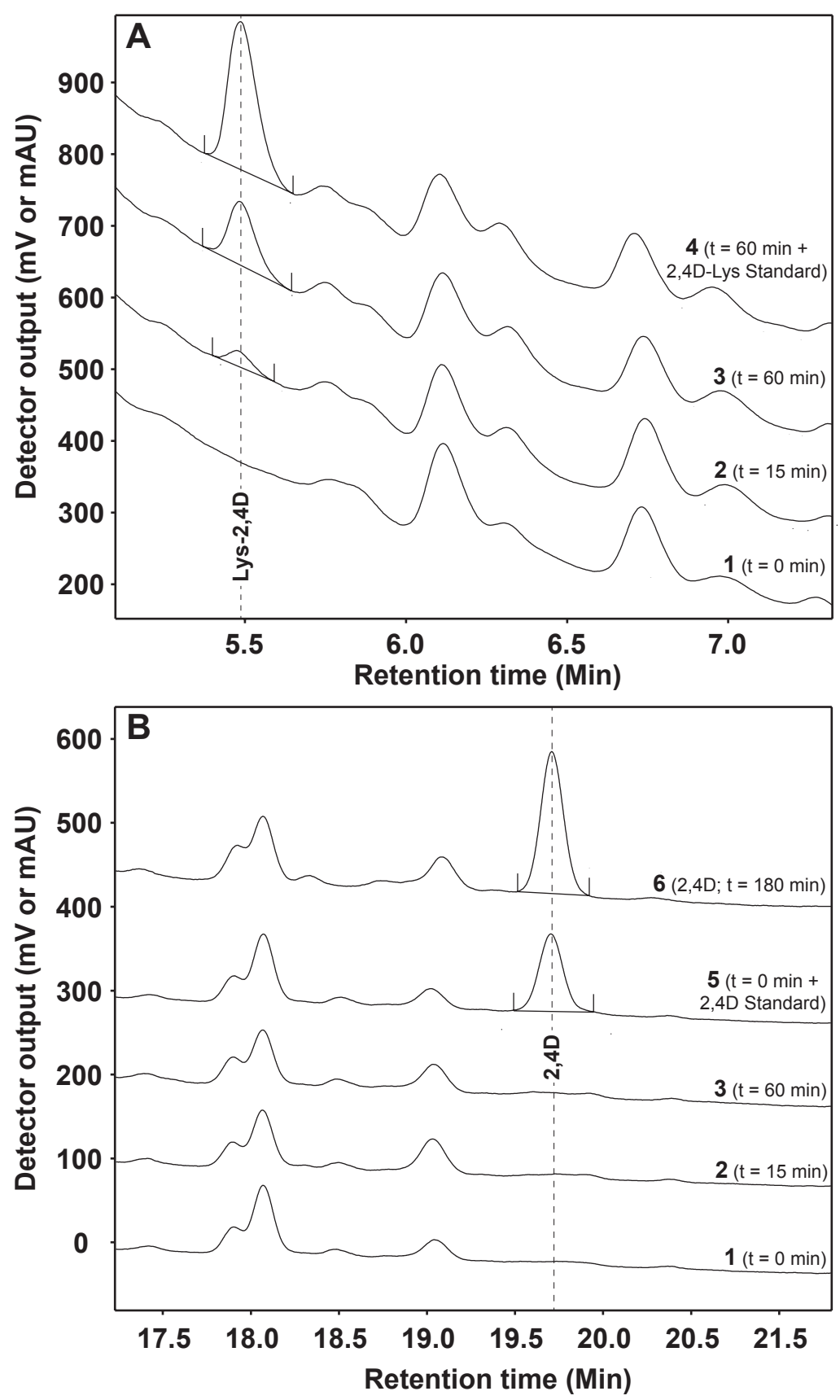

Figure 2. Study of 2,4D-L-Lys metabolism in $M$. pudica pulvini. A: when present, 2,4D-L-Lys appears on the first part of the chromatogram $(\mathrm{Rt}=5.5 \mathrm{~min}) .1$ : control, $\mathrm{t}=0$ (beginning of the experiment). 2,4D-L-Lys was detected after $15 \mathrm{~min}$ (2) and $60 \mathrm{~min}$ (3) incubation times. 2,4D-L-Lys standard was added to the $60 \mathrm{~min}$ extract to confirm its presence (4). B: when present, 2,4D appears at the end of the chromatogram ( $\mathrm{Rt}=19.7 \mathrm{~min})$. 5: $2,4 \mathrm{D}$ standard was added to the 0 min extract $(1$; control) to confirm its retention time in this matrix. Noteworthy, there was no trace of 2,4D after $15 \mathrm{~min}$ (2) and $60 \mathrm{~min}$ (3) incubation times with 2,4D-L-Lys. The same assay conducted with $2,4 \mathrm{D}$ alone at $100 \mu \mathrm{M}$ concentration on pulvini extracted after $180 \mathrm{~min}$ incubation showed the presence of $2,4 \mathrm{D}(6)$. 


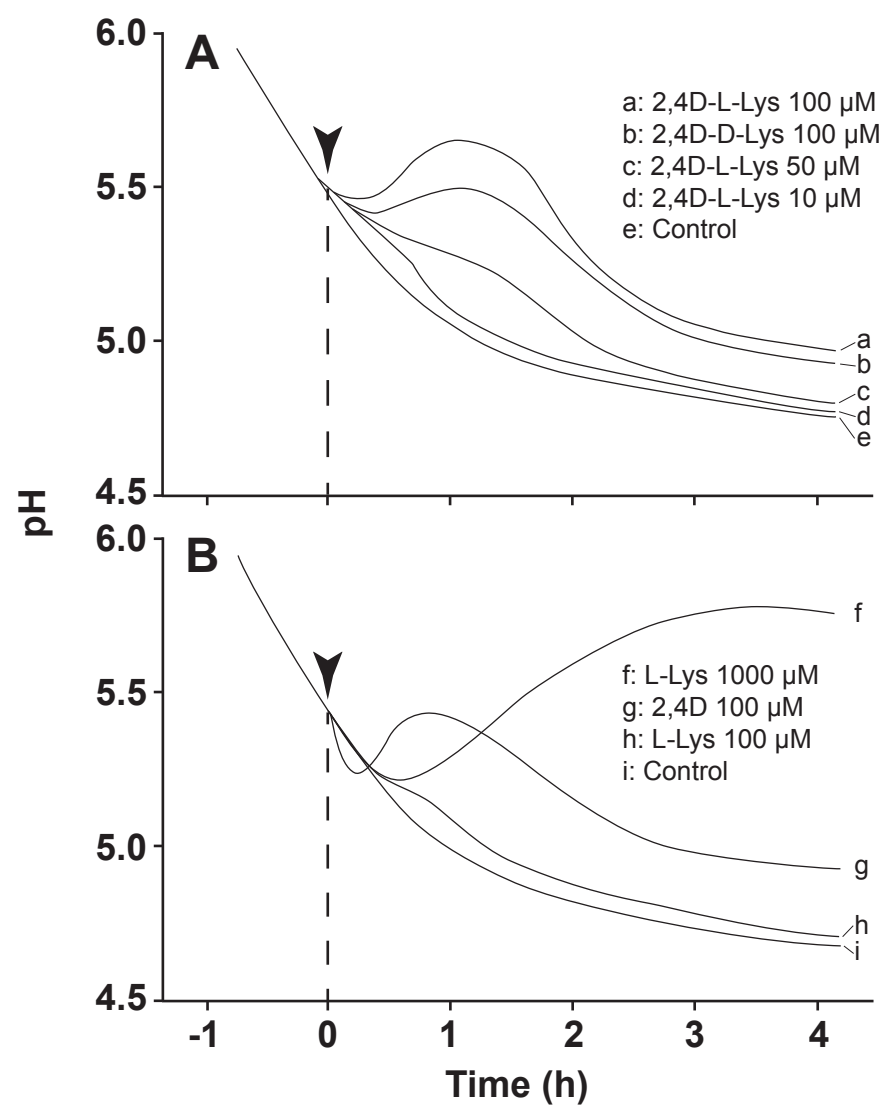

Figure 3: Representative time courses of $\mathrm{pH}$ variations monitored in the bathing medium of $M$. pudica pulvinar tissues induced by various compound additions (arrow heads). A: 2,4D-L-Lys at 10,50 and $100 \mu \mathrm{M}$ and by 2,4D-D-Lys at $100 \mu \mathrm{M}$. B: 2,4D at $100 \mu \mathrm{M}$ and lysine at 100 and $1000 \mu \mathrm{M}$. These experiments were repeated three times with similar results. 


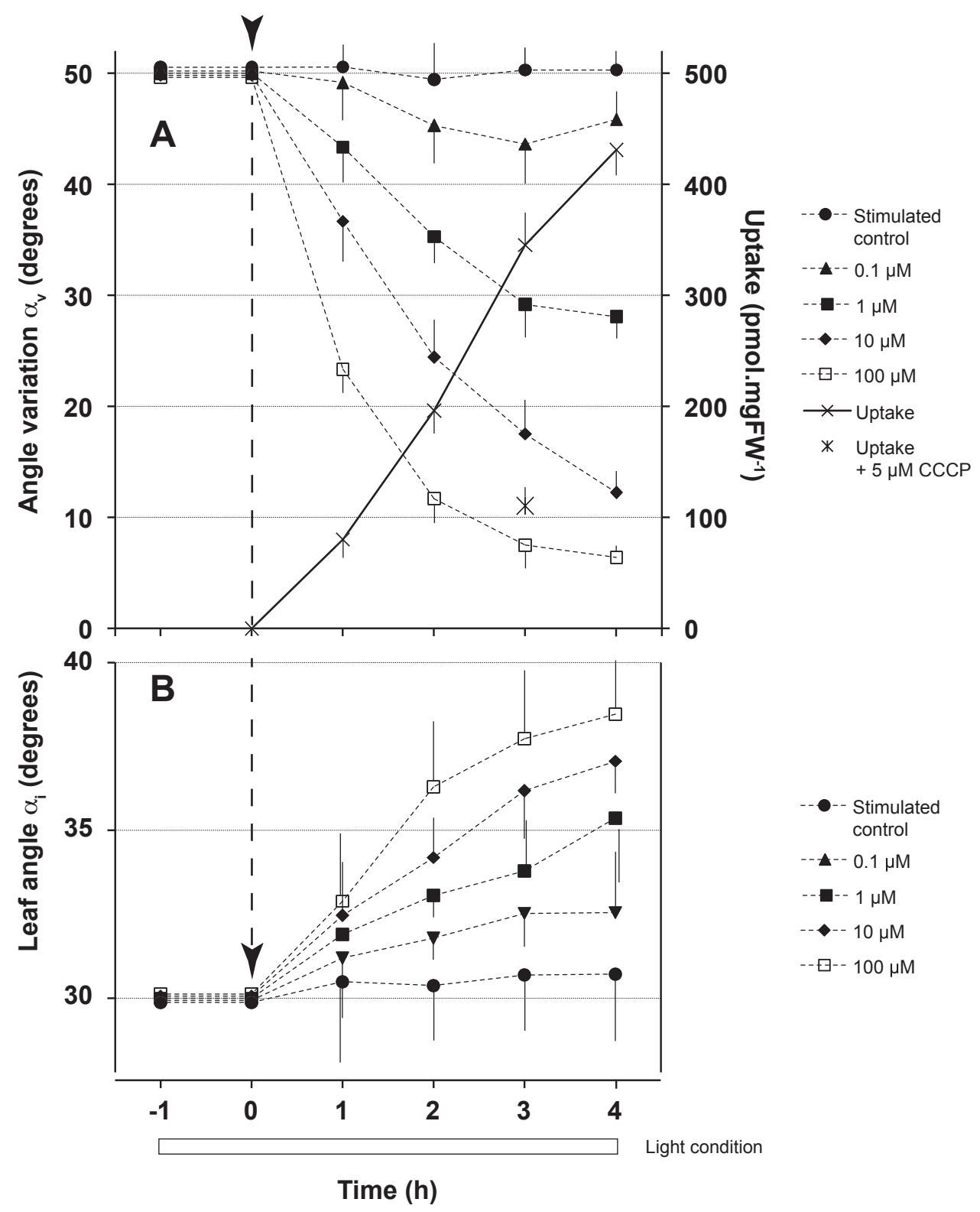

Figure 4: Effect of 2,4D-L-Lys on the drooping movement of $M$. pudica plantlet leaves induced by a touch applied each hour on the extensor part. A: Time course of the inhibition of the seismonastic pulvinar osmocontractile reaction following treatment with 2,4D-L-Lys (arrow head) at various concentrations as indicated in $\mu \mathrm{M}$. In bold line, time course of the amount of labelled compound absorbed by the pulvinar tissues incubating in a medium containing $100 \mu \mathrm{M} 2,4 \mathrm{D}-{ }^{3} \mathrm{H}-\mathrm{L}-\mathrm{Lys}(\mathrm{Mean} \pm \mathrm{SD}, \mathrm{n}=3$ ). B: Time course of the initial angle $\left(\alpha_{\mathrm{i}}\right)$ recovered after pulvinar stimulation following treatment with 2,4D-L-Lys at various concentrations as indicated in $\mu \mathrm{M}$. Each measurement was done just after $\left(\mathbf{A}, \alpha_{\mathrm{v}}\right)$ and just before $\left(\mathbf{B}, \alpha_{i}\right)$ the touch. Mean \pm SE, $n=30$. 

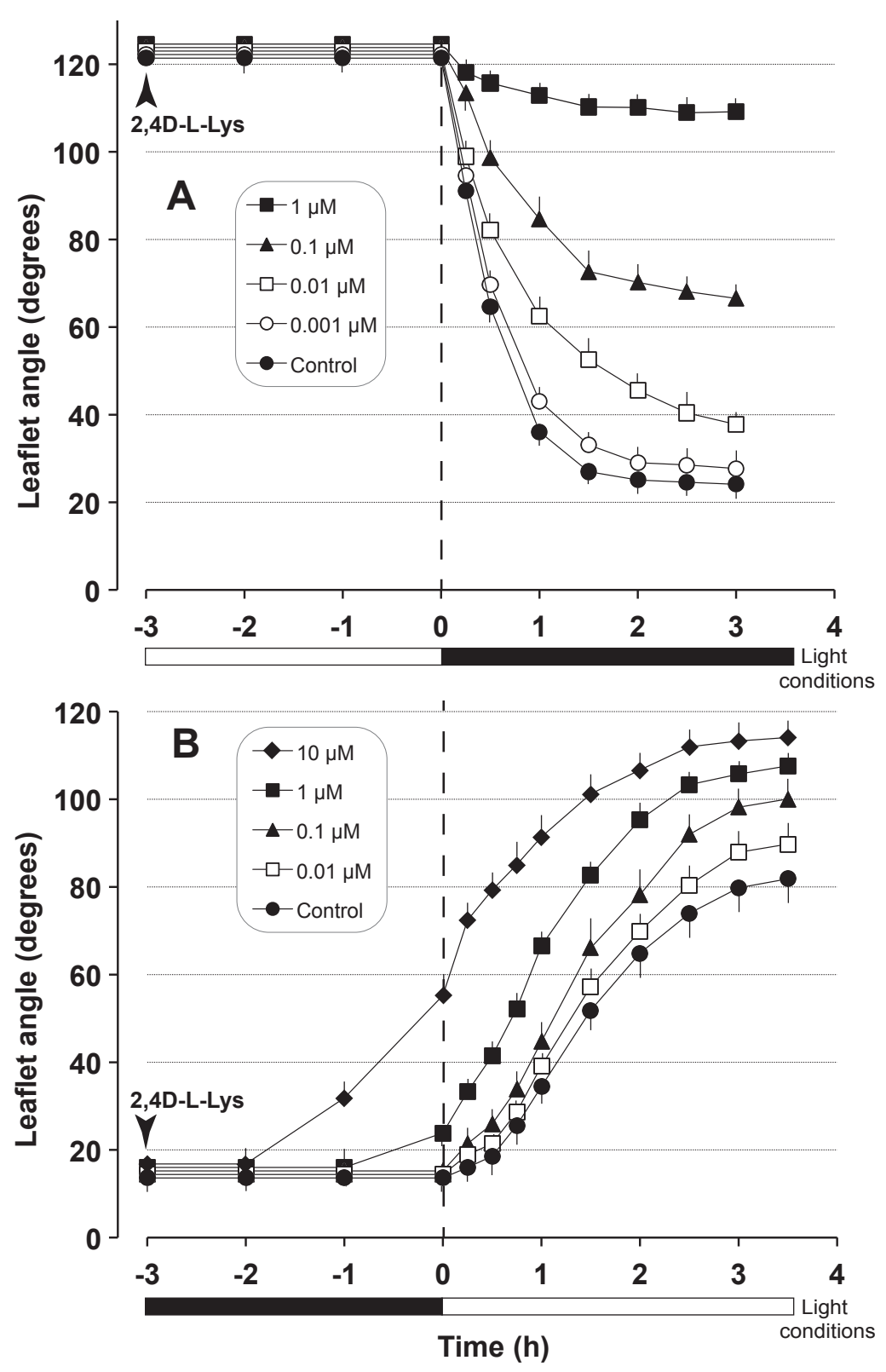

Figure 5: Effect of 2,4D-L-Lys on leaflet movements of C. fasciculata. Influence of various concentrations of the conjugate on the time course of the dark-induced (A) and lightinduced (B) reactions. The conjugate was applied for $180 \mathrm{~min}$ before the onset of the dark- or light period. Dark: the light was switched off in the middle of the photophase. Light: the light was switched on in the middle of the nyctophase of the photoperiodic cycle. Vertical bars represent SE of the mean. $n=24$. 

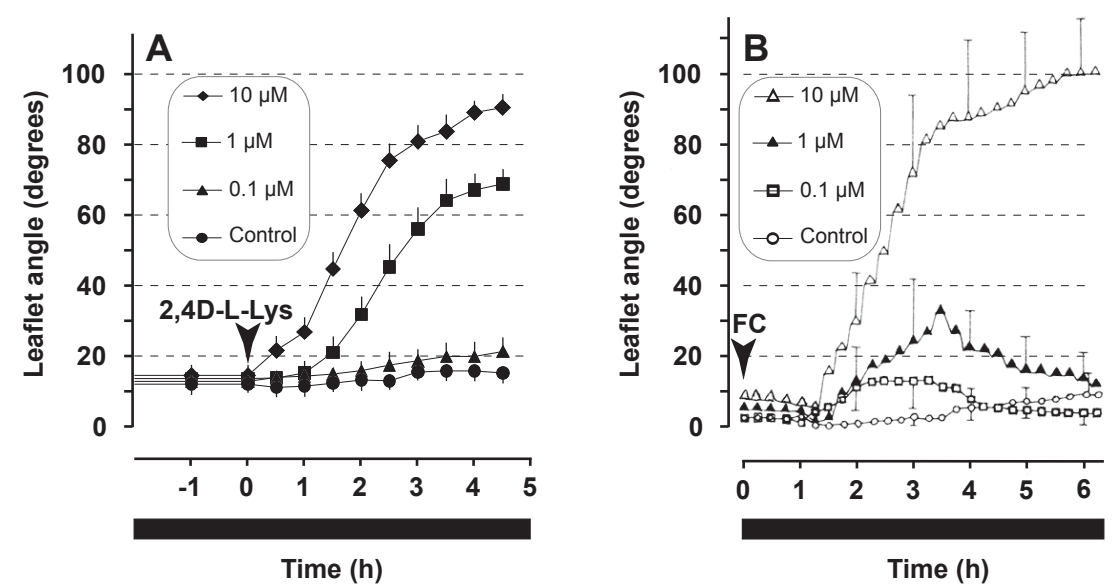

Figure 6: Comparison of the effects of 2,4D-L-Lys and fusicoccin on leaflet movements of $C$. fasciculata. Influence of various concentrations of 2,4D-L-Lys (A) or fusicoccin [FC] (B, from Bonnemain et al, 1978) on the time course of the leaflet movements without external signal (dark condition). Vertical bars represent SE of the mean, $n=24$ (A) or $\mathrm{n}=8(\mathrm{~B})$. 


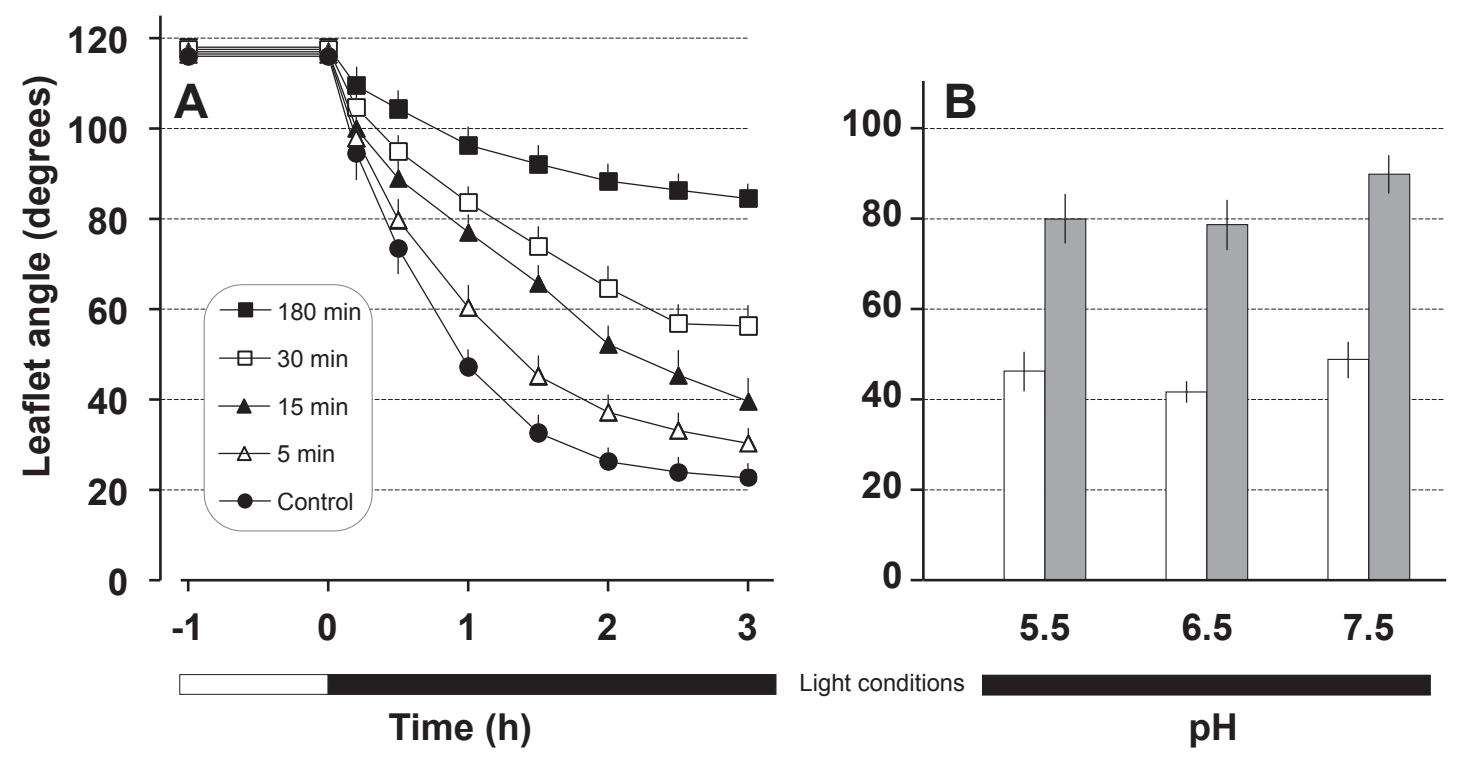

Figure 7: Effect of 2,4D-L-Lys treatments applied before the dark signal on the scotonastic closure of $C$. fasciculata leaflets. A: Effect of the treatment duration with $0.5 \mu \mathrm{M}$ 2,4D-L-Lys applied at 5, 15, 30 and $180 \mathrm{~min}$ before this signal. B: Effect of $0.1 \mu \mathrm{M} 2,4 \mathrm{D}-\mathrm{L}-$ Lys solution (black columns) at various $\mathrm{pH}$ values on angle variation $\left(\alpha_{\mathrm{v}}\right)$ compared to 2.5 $\mathrm{mM}$ buffer solutions used for dilution of the compound (white columns). 2,4D-L-Lys was applied for $180 \mathrm{~min}$ before the dark signal. Angles were calculated $1 \mathrm{~h}$ after the start of the dark period. Vertical bars represent SE of the mean; $n=24$. 


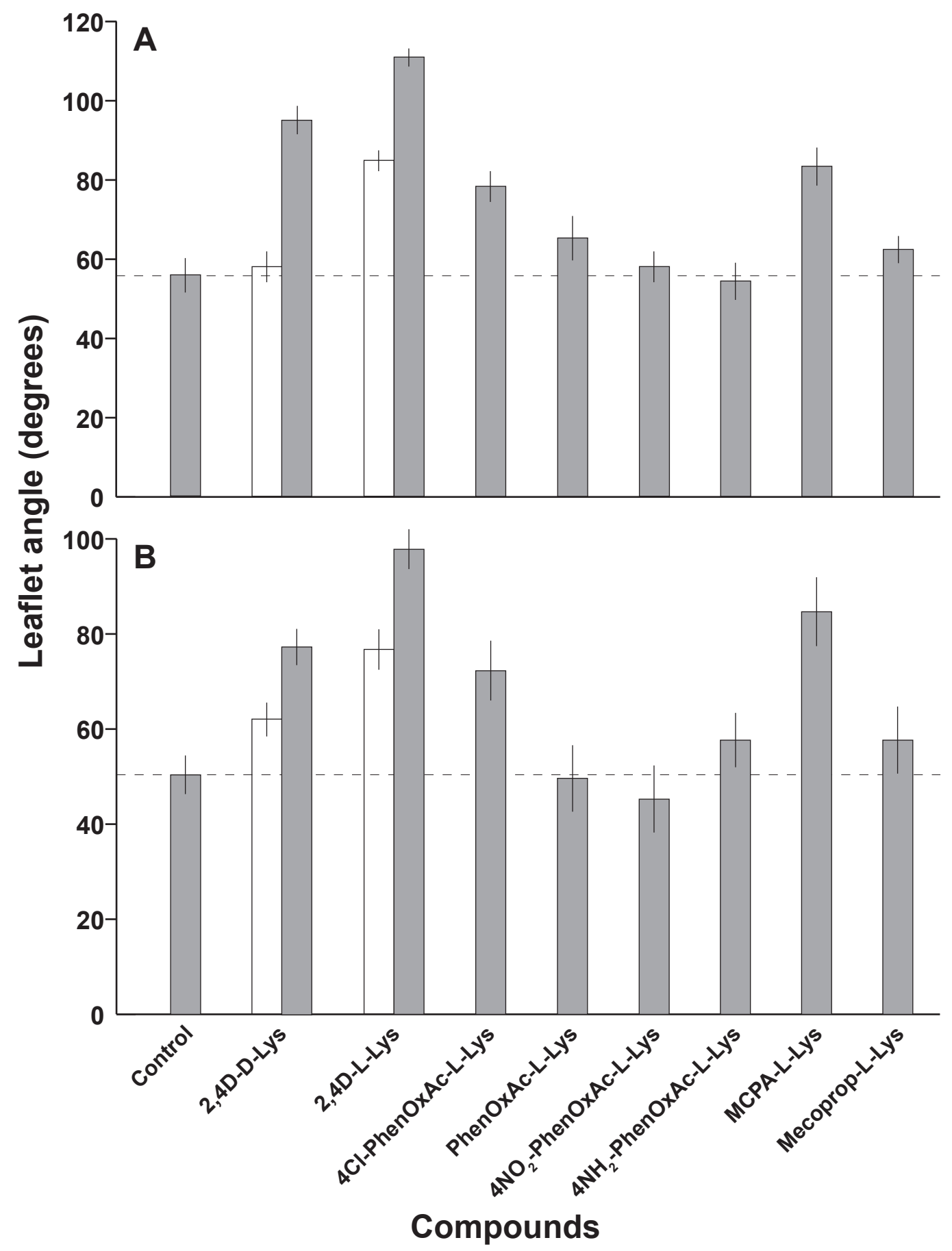

Figure 8. Comparative effects of 2,4D-L-Lys derivatives on dark-induced (A) and lightinduced (B) movements of C. fasciculata leaflets. Compounds were applied for $180 \mathrm{~min}$ before the onset of the dark- and light period. Angles were calculated $1 \mathrm{~h}$ after the start of the dark and light signals. See Table 1 for complete formula. White columns: $0.1 \mu \mathrm{M}$, grey columns: $1 \mu \mathrm{M}$. Vertical bars represent SE of the mean; $\mathrm{n}=24$. 